Keywords: Sludge, $A R P, M C U$, $m M S T, N G-C S S X, D W P F$

Retention: Permanent

\title{
DWPF Flowsheet Studies with Simulant to Determine the Impact of Next Generation Solvent on the CPC Process and Glass Formulation
}

\author{
J.D. Newell \\ D.K. Peeler \\ T.B. Edwards \\ M.S. Hay \\ M.E. Stone
}

June 30, 2011

Savannah River National Laboratory Savannah River Nuclear Solutions, LLC Aiken, SC 29808 
SRNL-STI-2011-00273

Revision 0

\section{DISCLAIMER}

This work was prepared under an agreement with and funded by the U.S. Government. Neither the U.S. Government or its employees, nor any of its contractors, subcontractors or their employees, makes any express or implied:

1. warranty or assumes any legal liability for the accuracy, completeness, or for the use or results of such use of any information, product, or process disclosed; or

2. representation that such use or results of such use would not infringe privately owned rights; or

3. endorsement or recommendation of any specifically identified commercial product, process, or service.

Any views and opinions of authors expressed in this work do not necessarily state or reflect those of the United States Government, or its contractors, or subcontractors.

\section{Printed in the United States of America \\ Prepared for \\ U.S. Department of Energy}


SRNL-STI-2011-00273

Revision 0

\section{REVIEWS AND APPROVALS}

AUTHORS:

J.D. Newell, Process Technology Programs

Date

D.K. Peeler, Process Technology Programs

Date

T.B. Edwards, Applied Comp Eng \& Statistics

Date

M.S. Hay, Adv Characterization \& Process

Date

M.E. Stone, Process Technology Programs

Date

TECHNICAL REVIEW:

D.P. Lambert, Process Technology Programs

Date

APPROVAL:

C.C. Herman, Manager

Date

Process Technology Programs

A.B. Barnes, Manager

Date

Engineering Process Development

S.D. Fink, Manager

Date

Separations Science Programs

S.L. Marra, Manager

Date

Environmental \& Chemical Process Technology Research Programs

B.A. Oard, Manager

Date

MCU Life Extension

John Occhipinti, Process Cognizant Engineering, Waste Solidification Engineering Date 


\section{ACKNOWLEDGEMENTS}

The authors would like to acknowledge Jack Zamnecik for his help in preparing the SRAT/SME equipment, refining the extraction procedures, and providing general background information on previously performed Isopar ${ }^{\circledR}$ L recovery experiments. Appreciation is expressed for the analytical guidance timely results provided by Steve Crump and Tom White.

The authors also acknowledge the hard work and long hours provided by the technicians: Tony Burckhalter, Jon DuVall, David Healy, Pat Simmons, Beverly Wall, Vickie Williams, and Phyllis Workman. Their efforts are greatly appreciated. 
SRNL-STI-2011-00273

Revision 0

\section{EXECUTIVE SUMMARY}

As a part of the Actinide Removal Process (ARP)/Modular Caustic Side Solvent Extraction Unit (MCU) Life Extension Project, a next generation solvent (NGS), a new strip acid, and modified monosodium titanate (mMST) will be deployed. The NGS is comprised of four components: $0.050 \mathrm{M}$ MaxCalix (extractant), 0.50 M Cs-7SB (modifier), $0.003 \mathrm{M}$ guanidine-LIX-79, with the balance $(\sim 74 \mathrm{wt} \%)$ being Isopar ${ }^{\circledR}$ L. The strip acid will be changed from dilute nitric acid to dilute boric acid $(0.01 \mathrm{M})$. Because of these changes, experimental testing with the next generation solvent and mMST was required to determine the impact of these changes in 512-S and Defense Waste Processing Facility (DWPF) operations, as well as Chemical Process Cell (CPC), glass formulation activities, and melter operations. Because of these changes, experimental testing with the next generation solvent and mMST is required to determine the impact of these changes.

A Technical Task Request (TTR) was issued to support the assessments of the impact of the next generation solvent and mMST on the downstream DWPF flowsheet unit [1]. The TTR identified five tasks to be investigated:

1. CPC Flowsheet Demonstration for NGS

2. Solvent Stability for DWPF CPC Conditions

3. Glass Formulation Studies

4. Boron Volatility and Melt Rate

5. CPC Flowsheet Demonstration for mMST

CPC Flowsheet studies were performed to determine the impact of the boric acid strip effluent, including organics, on the CPC SRAT/Slurry Mix Evaporator (SME) process. From these tests, the following was determined:

- No significant negative impacts to process chemistry were observed from the addition of $0.01 \mathrm{M}$ boric acid strip effluent when an equivalent amount of nitric and formic acids was deducted from the normal acid addition.

- Off-gas data for NGS-2 (boric acid run) and NGS-3 (baseline run) indicate that the addition of the strip effluent containing $0.01 \mathrm{M}$ boric acid will not result in excessive hydrogen gas generation.

- SRAT/SME product $\mathrm{pH}$ and dissolved metal content were not impacted by the change in strip acid.

- At insoluble solids greater than $42 \mathrm{wt} \%$, yield stress for NGS-2 (boric acid run) increases more rapidly than that of NGS-1 (baseline run).

A series of five SRAT cycles were performed to determine how the solvent partitions throughout the SRAT equipment. This was accomplished by performing five back-to-back SRAT cycles. From these tests, the following was determined:

- $93 \%$ of Isopar ${ }^{\circledR} \mathrm{L}$ was recovered.

○ Most (90\%) of the Isopar ${ }^{\circledR}$ L was in the offgas system on the carbon tubes.

- $67 \%$ of the modifier was recovered.

O Of the total amount of modifier recovered, $41 \%$ was recovered from the SRAT vessel, $30 \%$ from the SMECT, and $23 \%$ in the MWWT.

- None of the modifier was found on the carbon tubes.

- Partitioning was similar to previous studies performed with the current solvent. 
Tests to determine if Isopar ${ }^{\circledR} \mathrm{L}$ accumulates in the SRAT at lower operating temperatures were performed at $92{ }^{\circ} \mathrm{C}$. This was done using both the current solvent and the next generation solvent.

For IA1 (Isopar Accumulation - new solvent) Isopar ${ }^{\circledR}$ L total mass recovery was $85 \%$.

- For IA2 (Isopar Accumulation - current solvent) Isopar ${ }^{\circledR}$ L total mass recovery was $90 \%$.

- All Isopar ${ }^{\circledR} \mathrm{L}$ was found on the carbon tubes except for $18 \%$ recovery of Isopar ${ }^{\circledR} \mathrm{L}$ in the FAVC for the current solvent.

- For IA 1 modifier total mass recovery was $67 \%$.

- For IA2, modifier total mass recovery was $69 \%$.

$\circ$ For both solvents, almost all $(\sim 94 \%)$ of the recovered modifier remained in the SRAT vessel.

During processing at DWPF, the possibility exists for contact of the MCU solvent with other process streams. To this end, the stability of the strip effluent and solvent was determined by mixing both with nitric acid, formic acid, sludge simulant, agitator oil, and sodium hydroxide at both boiling and room temperatures. It was also requested that radiation stability tests be performed on the next generation solvent.

- In all room temperature cases, Isopar ${ }^{\circledR} \mathrm{L}$ recovery was less than $25 \%$.

- Modifier recovery was about the same for boiling vs. room temperature reactions.

- Analyses of the condensates, SRAT products, and carbon tubes revealed that there were no analytes that resulted from decomposition of the organic solvent at either room temperature or boiling.

- A literature review and paper study was performed to determine the stability of the next generation solvent in a radiation field and the impact on DWPF if degradation were to occur [1].

- No significant decomposition of the baseline solvent components has been noted when subjected to a radiation field.

- A literature review indicated that boric acid is compatible with agitator oil.

The downstream impacts of the boric acid strip effluent (SE) to the glass formulation activities and melter operations were considered. A separate report has been issued detailing these results, and a brief summary of those are results are provided in this report [10]. The results of the paper study assessment indicate that Frit 418 and Frit 418-7D are robust to the implementation of the $0.01 \mathrm{M}$ boric acid SE into the SB7b flowsheet. Results indicate that even if SE is not transferred to the SRAT, there would be no need to add boric acid (from a trim tank) to compositionally compensate for the absence of the boric acid SE in either a sludge-only or ARP-added SB7b flowsheet. This is coupled with the fact that the $\mathrm{B}_{2} \mathrm{O}_{3}$ concentration in the Frit $418(8 \mathrm{wt} \%)$ is the lowest $\mathrm{B}_{2} \mathrm{O}_{3}$ concentration (in frit) that DWPF is expected to process. With higher $\mathrm{B}_{2} \mathrm{O}_{3}$ containing frits, the amount of boron from the $\mathrm{SE}$ as a percentage of the boron in the frit becomes more negligible. 


\section{TABLE OF CONTENTS}

LIST OF TABLES viii

LIST OF FIGURES viii

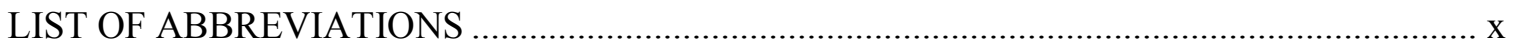

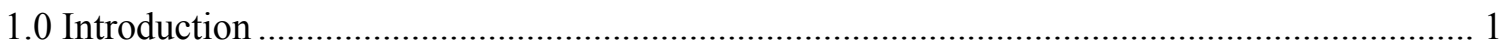

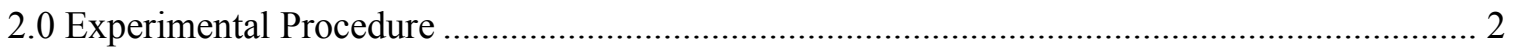

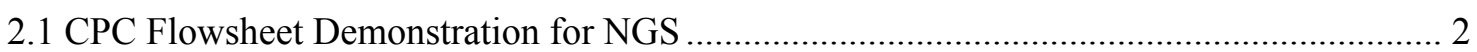

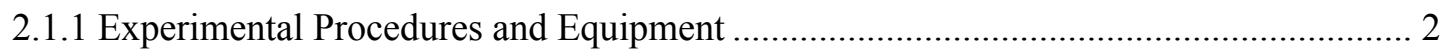

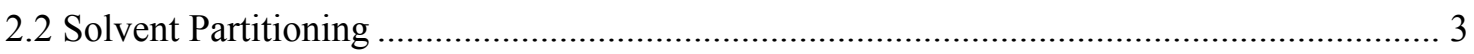

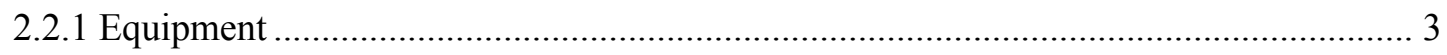

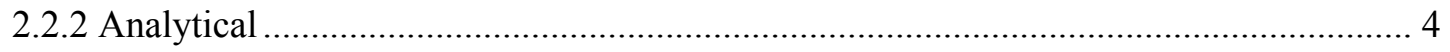

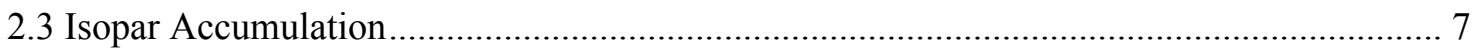

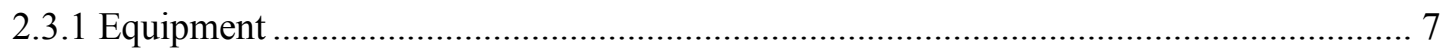

2.4 Next Generation Solvent Stability for DWPF CPC Conditions ......................................... 7

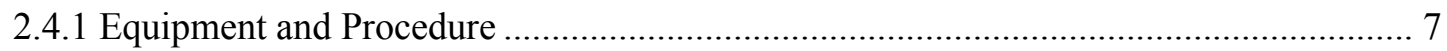

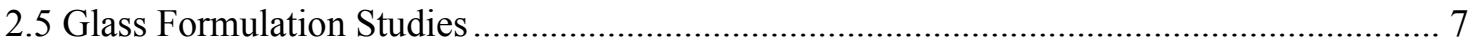

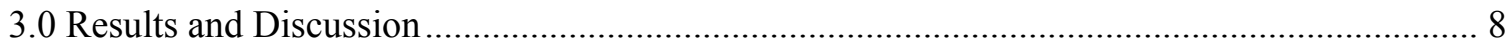

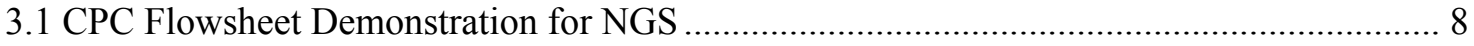

3.1.1 SRAT/SME Processing for Boric Acid Flowsheet Study ............................................ 8

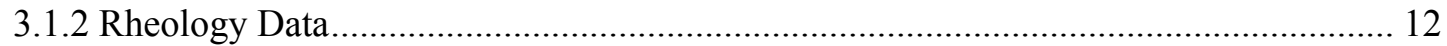

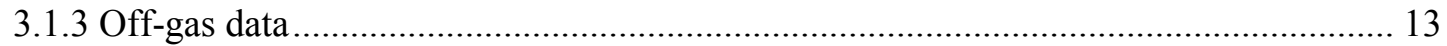

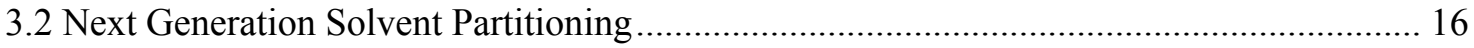

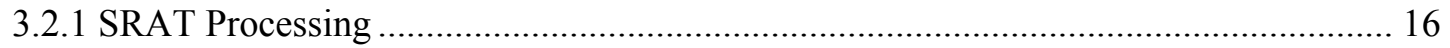

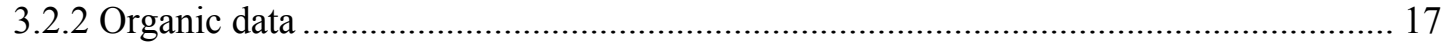

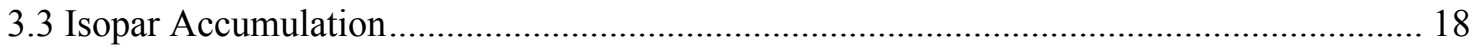

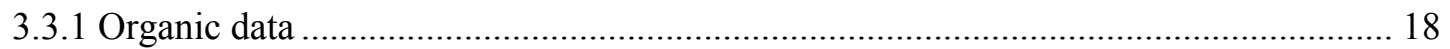

3.4 Next Generation Solvent Stability for DWPF CPC Conditions ......................................... 19

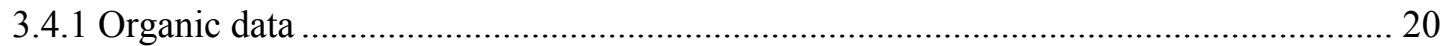

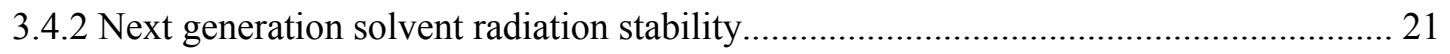

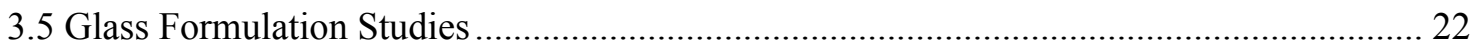

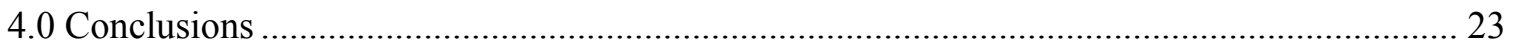

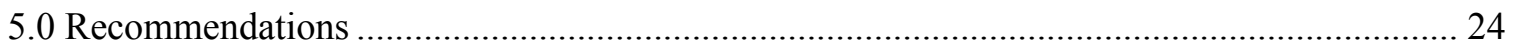

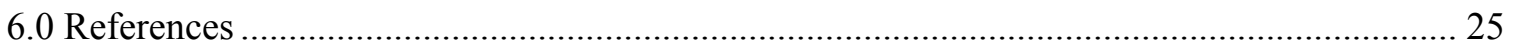




\section{LIST OF TABLES}

Table 1: Compositional differences in solvents .................................................................... 1

Table 2: wt $\%$ Calcined Elemental Composition Final Sludge .................................................. 9

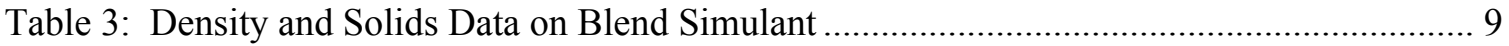

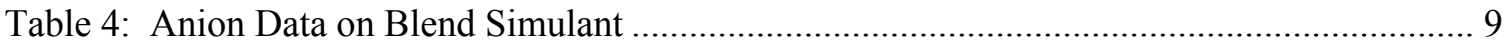

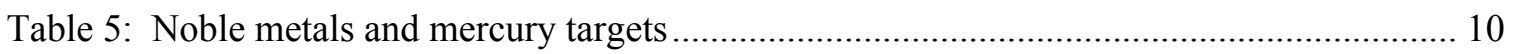

Table 6: Formate and Nitrite Results in SRAT and SME Cycles.............................................. 10

Table 7: Percentages of selected elements in supernate after acid addition ............................... 11

Table 8: Percentage of selected elements in SME product supernate ........................................ 11

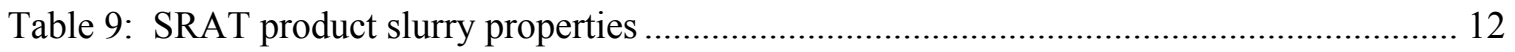

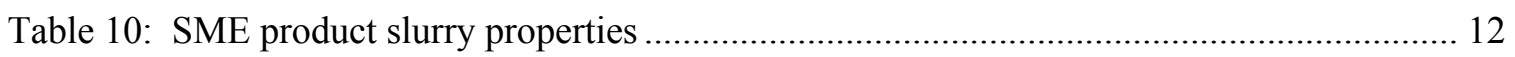

Table 11: Rheology data for NGS-1 and NGS-2 SRAT/SME cycles ....................................... 13

Table 12: Stoichiometric acid calculation results, mol acid/L slurry ….................................... 15

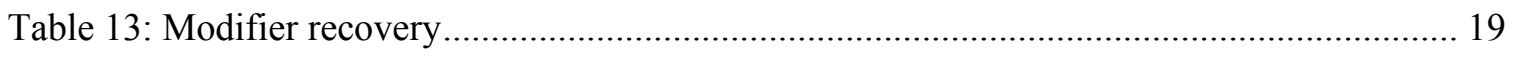

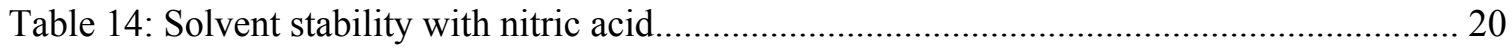

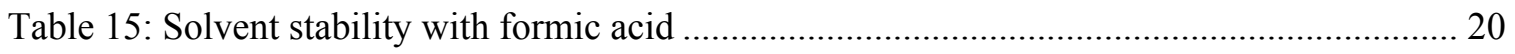

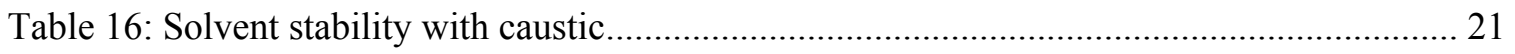

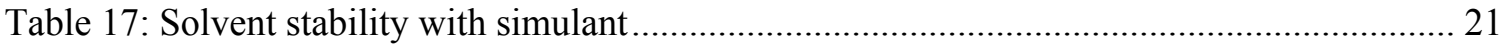

\section{LIST OF FIGURES}

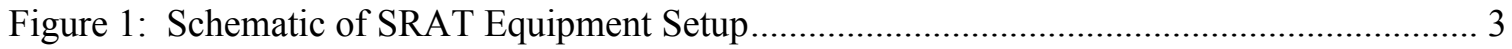

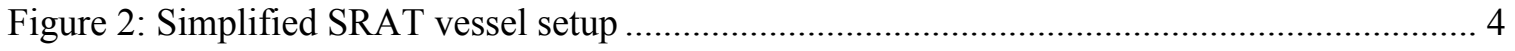

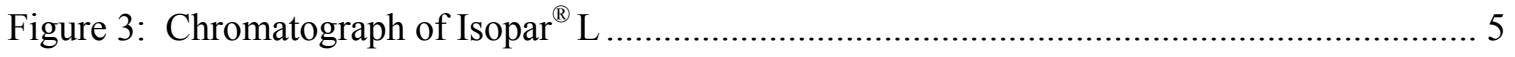

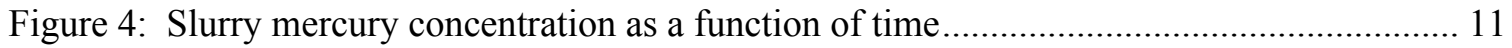

Figure 5: NGS1 and NGS2 SME product rheology at varying insoluble solids ......................... 13

Figure 6: SRAT Cycle Hydrogen Generation, lb/hr DWPF Scale ............................................ 14

Figure 7: SME Cycle Hydrogen Generation, lb/hr DWPF Scale .............................................. 14 
Figure 8: SRAT Cycle Carbon Dioxide Generation, lb/hr DWPF Scale ..... 15

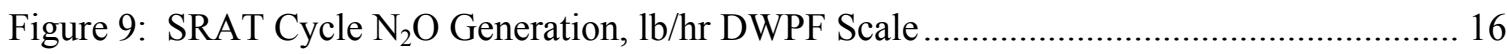

Figure 10: SRAT Cycle Oxygen Consumption, lb/hr DWPF Scale.. 16 
SRNL-STI-2011-00273

Revision 0

\section{LIST OF ABBREVIATIONS}

$\begin{array}{ll}\text { ACTL } & \text { Aiken County Technology Laboratory } \\ \text { AD } & \text { Analytical Development } \\ \text { ARP } & \text { Actinide Removal Process } \\ \text { CETL } & \text { Clemson Engineering Technology Laboratory } \\ \text { CPC } & \text { Chemical Process Cell } \\ \text { DI } & \text { Deionized Water } \\ \text { DWPF } & \text { Defense Waste Processing Facility } \\ \text { FAVC } & \text { Formic Acid Vent Collector } \\ \text { GC } & \text { Gas Chromatograph } \\ \text { GC/MS } & \text { Gas Chromatography/Mass Spectrometry } \\ \text { HPLC } & \text { High Pressure Liquid Chromatography } \\ \text { ICP-AES } & \text { Ion Coupled Plasma - Atomic Emission Spectrometry } \\ \text { ITS } & \text { Immobilization Technology Section } \\ \text { MAR } & \text { Measurement Acceptability Region } \\ \text { MCU } & \text { Modular Caustic Side Solvent Extraction Unit } \\ \text { mMST } & \text { Modified Monosodium Titanate } \\ \text { MWWT } & \text { Mercury Water Wash Tank } \\ \text { NG-CSSX } & \text { Next Generation - Caustic Side Solvent Extraction } \\ \text { NGS } & \text { Next Generation Solvent } \\ \text { NIOSH } & \text { National Institute for Occupational Safety and Health } \\ \text { PSAL } & \text { Process Science Analytical Laboratory } \\ \text { PTP } & \text { Process Technology Programs } \\ \text { SB } & \text { Sludge Batch } \\ \text { SE } & \text { Strip Effluent } \\ \text { SME } & \text { Slurry Mix Evaporator } \\ \text { SMECT } & \text { Slurry Mix Evaporator Condensate Tank } \\ \text { SRNL } & \text { Savannah River National Laboratory } \\ \text { SRR } & \text { Savannah River Remediation } \\ \text { SRAT } & \text { Sludge Receipt Adjustment Tank } \\ \text { SVOA } & \text { Semivolatile Organic Analysis } \\ \text { TIC } & \text { Total Inorganic Carbon } \\ \text { TTQAP } & \text { Task Technical and Quality Assurance Plan } \\ \text { TTR } & \text { Technical Task Request } \\ \text { VOA } & \text { Volatile Organic Analysis } \\ \text { WL } & \text { Waste Loading } \\ & \end{array}$


SRNL-STI-2011-00273

Revision 0

\subsection{Introduction}

The Actinide Removal Process (ARP)/Modular Caustic Side Solvent Extraction Unit (MCU) Life Extension includes activities required to support ARP/MCU extended operations to treat dissolved salt cake waste (remove actinides, strontium, and cesium) and deliver a low-activity decontaminated salt solution waste stream to the Saltstone Processing Facility (SPF). The resulting cesium and actinide/strontium salt stream is processed in the Defense Waste Processing Facility (DWPF). As a part of the ARP/MCU Life Extension Project, a next generation solvent (NGS), a new strip acid, and modified monosodium titanate (mMST) will be deployed. The NGS

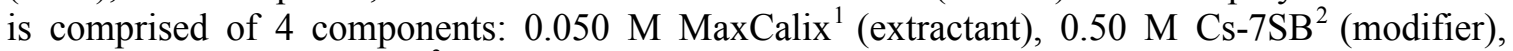
$0.003 \mathrm{M}$ guanidine-LIX-793 ${ }^{3}$, with the balance $(\sim 74 \mathrm{wt} \%)$ being Isopar ${ }^{\circledR}$ L. The strip acid will be changed from dilute nitric acid to dilute boric acid $(0.01 \mathrm{M})$. Table 1 shows the compositional differences between the next generation solvent and currently used solvent.

Table 1: Compositional differences in solvents

\begin{tabular}{||l|c|c|}
\hline \hline & $\begin{array}{c}\text { Next Generation } \\
\text { Solvent }\end{array}$ & $\begin{array}{c}\text { Current } \\
\text { Solvent }\end{array}$ \\
\hline Extractant, wt\% & 5.62 & 0.94 \\
\hline Modifier, wt\% & 19.78 & 29.80 \\
\hline Suppressor, wt $\%$ & 0.17 & 0.12 \\
\hline Isopar ${ }^{\circledR} \mathrm{L}, \mathrm{wt} \%$ & 74.47 & 69.14 \\
\hline Density, g/mL & 0.83 & 0.85 \\
\hline
\end{tabular}

Because of these changes, experimental testing with the next generation solvent and mMST is required to determine the impact of these changes in 512-S and DWPF operations as well as Chemical Process Cell (CPC), glass formulation activities, and melter operations.

A Technical Task Request (TTR) was issued to support the assessments of the impact of the next generation solvent and mMST on the downstream DWPF flowsheet unit [2]. The TTR identified five tasks to be investigated:

1. CPC Flowsheet Demonstration for NGS

2. Solvent Stability for DWPF CPC Conditions

3. Glass Formulation Studies

4. Boron Volatility and Melt Rate

5. CPC Flowsheet Demonstration for mMST

In response to the TTR, a Task Technical and Quality Assurance Plan (TTQAP) was issued by the Savannah River National Laboratory (SRNL) which outlined the technical approach to be used to meet programmatic objectives [3]. The downstream impacts of the boric acid strip effluent to the glass formulation activities and melter operations (Tasks 3 and 4) as well as the impacts of the strip effluent acid change to boric acid on the CPC system (Task 1) have been previously reported [4], but are summarized in this report. Task 5, CPC Flowsheet Demonstration for mMST will be discussed in a forthcoming report upon completion of testing.

\footnotetext{
${ }^{1}$ MaxCalix is 1,3-alt-25,27-bis(3,7-dimethyloctyl-1-oxy)calix[4]arene-benzocrown-6, an extractant to remove cesium.

${ }^{2}$ The Modifier is 1-(2,2,3,3-tetrafluoropropoxy)-3-(4-sec-butylphenoxy)-2-propanol, added to increase the soluble concentration of the extractant.

${ }^{3}$ LIX $^{\circledR} 79$ guanidine is $N, N$ '-dicyclohexyl- $N$ '-isotridecylguanidine, added to prevent - or suppress - the deleterious impact of trace organics on stripping of cesium from the solvent.
} 
Details of the SRAT testing, R\&D directions, acid calculations, and data are found in notebook SRNL-NB-2010-00177.

\subsection{Experimental Procedure}

This section describes the approach that was used to perform the tests on tasks 1-4 identified in the TTR. It is divided into four subsections. Section 2.1 describes the CPC flowsheet demonstrations which include Sludge Receipt Adjustment Tank (SRAT)/Slurry Mix Evaporator (SME) cycles using sludge simulant and boric acid. Section 2.2 describes the next generation solvent partitioning over five back-to-back SRAT cycles, and Section 2.3 presents the Isopar accumulation test. Section 2.4 presents the solvent stability tests. Section 2.5 summarizes the conclusions from the previously reported glass formulation studies.

\subsection{CPC Flowsheet Demonstration for NGS}

As a part of the ARP/MCU Life Extension Project, a NGS, a new strip acid, and modified monosodium titanate (mMST) will be deployed. The NGS is comprised of four components: $0.050 \mathrm{M}$ MaxCalix (cesium extractant), 0.50M Cs-7SB (diluent modifier), 0.003M guanidine (suppressor), with the remainder $(\sim 75 \mathrm{wt} \%)$ Isopar ${ }^{\circledR} \mathrm{L}$ (diluent). The strip acid will be changed from dilute $(0.001 \mathrm{M})$ nitric acid to dilute $(0.01 \mathrm{M})$ boric acid.

\subsubsection{Experimental Procedures and Equipment}

Testing was performed at the Aiken County Technology Laboratory (ACTL) using 4L kettles to replicate both the SRAT and SME. Connected to the kettle are the SRAT Condenser, Mercury Water Wash Tank (MWWT), ammonia scrubber, and the Formic Acid Vent Condenser (FAVC). The Slurry Mix Evaporator Condensate Tank (SMECT) was a separate bottle that was fed by the MWWT. The experiments were performed in accordance with Procedure ITS-0094, "Laboratory Scale Chemical Process Cell Simulations," of Manual L29. A schematic of the SRAT equipment setup used for the boric acid flowsheet study is presented in Figure 1. 


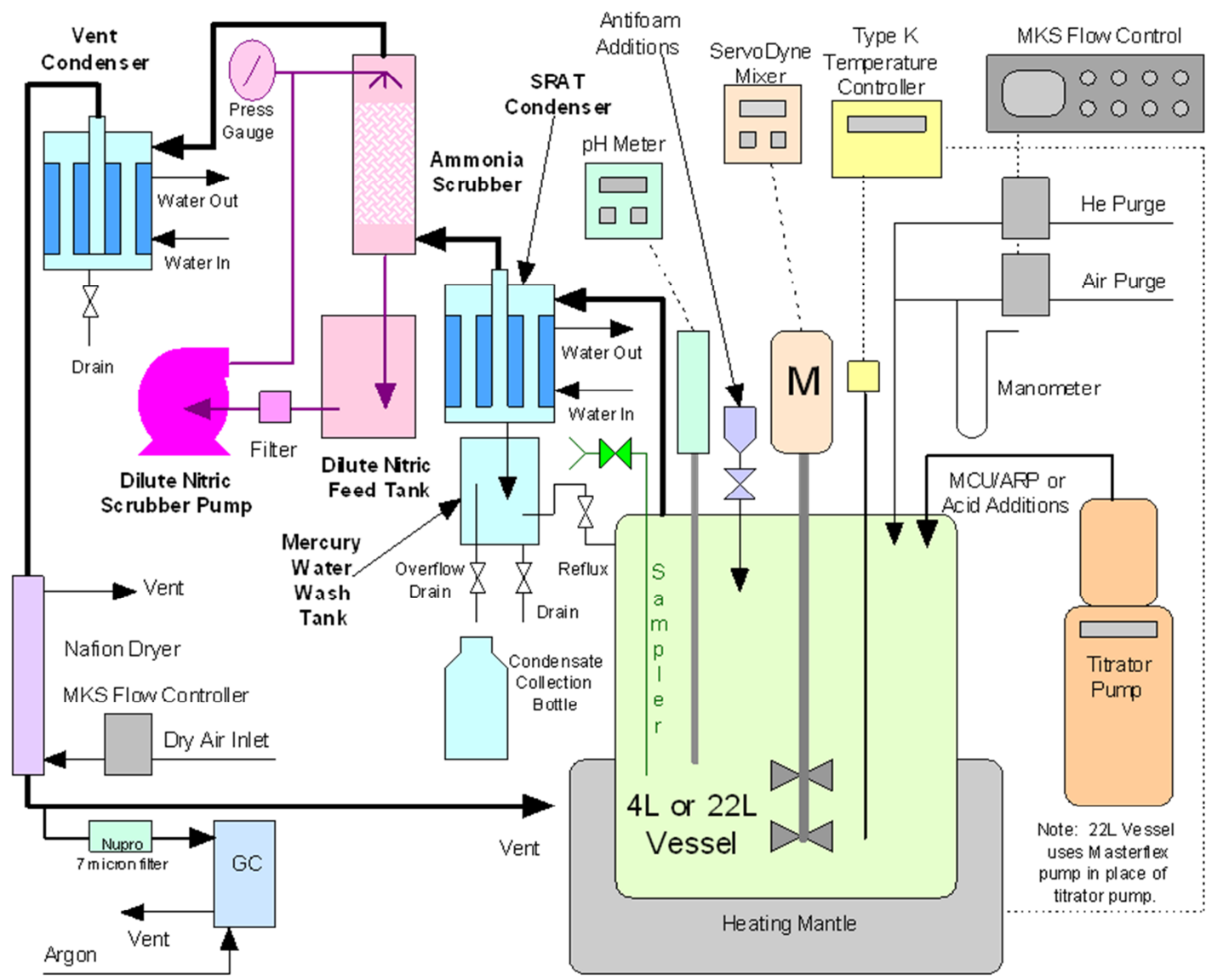

Figure 1: Schematic of SRAT Equipment Setup

SRAT/SME experiments were performed for both the baseline and boric acid strip effluent flowsheets. Directions for these experiments can be found in notebook SRNL-NB-2010-00177.

\subsection{Solvent Partitioning}

A series of five SRAT cycles were performed to determine how the solvent partitions throughout the SRAT equipment. This was accomplished by performing five back-to-back SRAT cycles. Each cycle utilized 2,691g of $\mathrm{ABC}$ simulant leaving a $625 \mathrm{~mL}$ heel between runs. MCU additions were added at an amount of 2,231g of boric acid and $0.338 \mathrm{~mL}$ of solvent.

\subsubsection{Equipment}

A simplified SRAT rig was used for the solvent partitioning studies. The setup was similar to the one used during the boric acid strip effluent flowsheet studies (Figure 1) with the exception of the use of the ammonia scrubbers and Nafion dryer (Figure 2). 
SRNL-STI-2011-00273

Revision 0

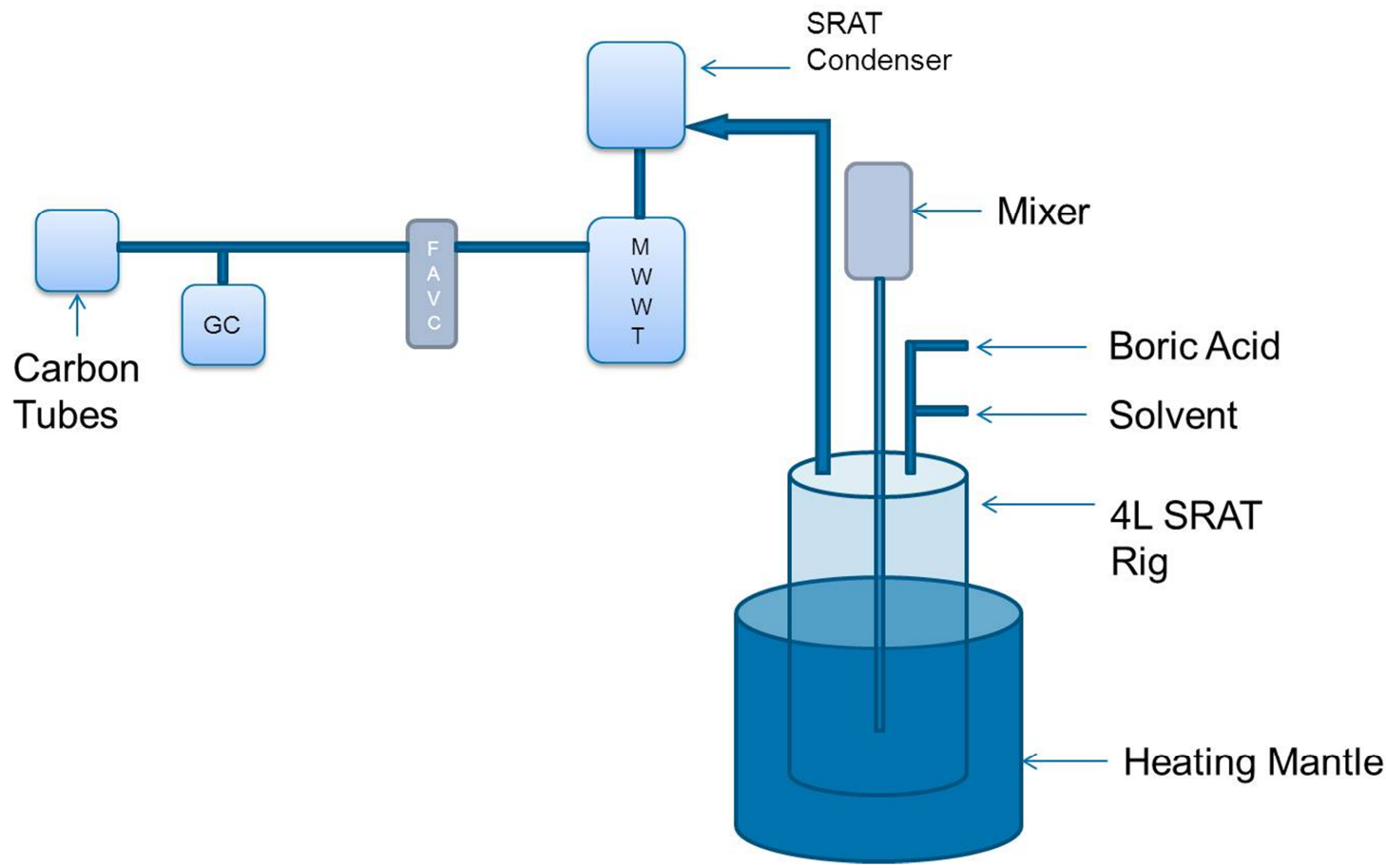

Figure 2: Simplified SRAT vessel setup

\subsubsection{Analytical}

Previous work served as a guide for conducting most of these experiments [5-7]. Since completing the organic material balance was the primary objective of this testing, a significant quantity of samples were submitted for organic analyses. Analytical Development (AD) analyzed the SRAT product, condensate samples, and the vessel rinses to quantify the concentrations of Isopar ${ }^{\circledR} \mathrm{L}$ and modifier. The Process Science Analytical Laboratory (PSAL) analyzed the SRAT product to quantify the concentrations of anions, cations, and solids along with measuring the density and $\mathrm{pH}$.

Isopar ${ }^{\circledR} \mathrm{L}$ is comprised of a multitude of aliphatic branch-chained hydrocarbon compounds that all share the sample distillation fraction point. Therefore, analysis with Gas Chromatography must take into account the total sum of all peaks resulting from the Isopar ${ }^{\circledR} \mathrm{L}$. The results for these analyses were all reported as the summation of the integrated peak areas of each peak within a given retention period. Figure 3 shows a chromatogram of Isopar ${ }^{\mathbb{R}} \mathrm{L}$, with a retention period of 8 minutes to 14 minutes (nominally). 
SRNL-STI-2011-00273

Revision 0

Figure 3: Chromatograph of $\operatorname{Isopar}^{\circledR} \mathbf{L}$

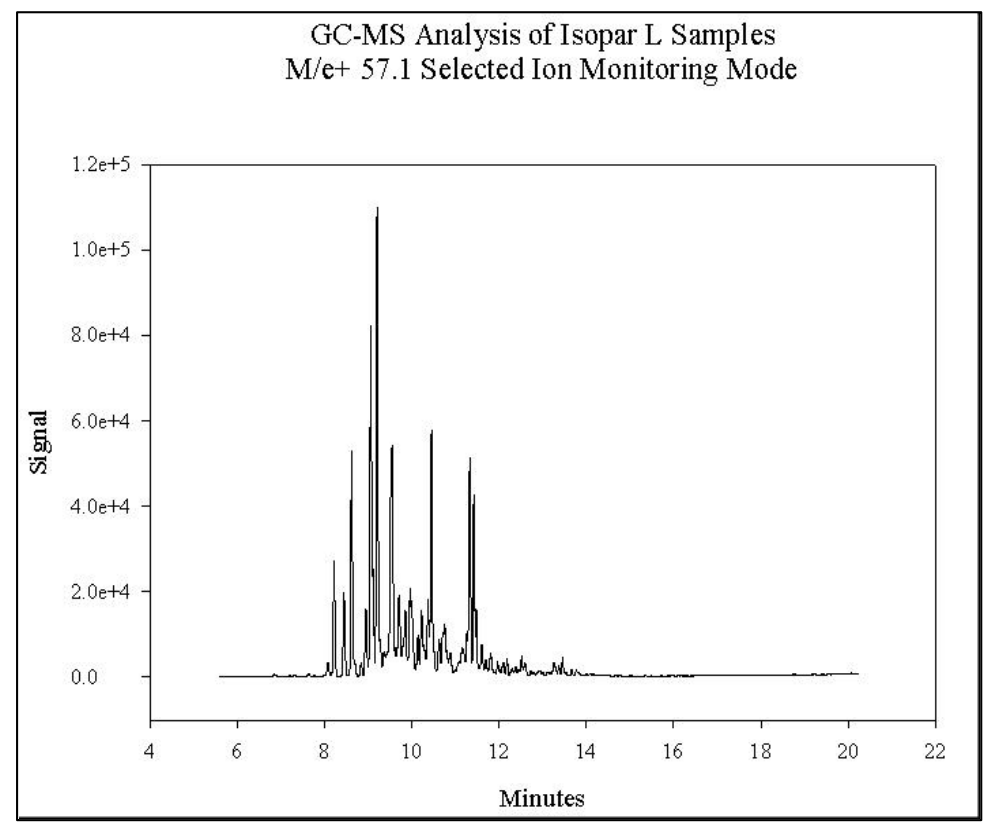

The calibration curve for Isopar ${ }^{\circledR} \mathrm{L}$ was calculated using a weighted linear regression using one over the square of the concentration as the weighting factor. This weighting factor keeps the fitted equation as close to the low concentration standard as to the high concentration standard. The typical $r^{2}$ for the calibration curve is 0.999 or greater.

Gas Chromatography/Mass Spectrometry (GC/MS) was used for semivolatile organic compound (SVOC) analysis. Isopar ${ }^{\mathbb{B}} \mathrm{L}$ results were reported from this method. Analytical separations were carried out on a Hewlett Packard 6890 gas chromatograph, equipped with a 30 meter DB-XLB column, with $0.18 \mathrm{~mm}$ diameter and 0.18 micron film thickness. Quantification was performed using a Hewlett Packard 5973 mass selective detector. The mass spectrometer tuning was confirmed within 24 hours prior to each measurement using perfluorotributylamine. When necessary, samples were prepared by extracting each sample with a known amount of hexane. If the sample was a vessel rinse that already contained hexane, this additional extraction was not necessary and only a spike was performed. Isopar ${ }^{\mathbb{B}} \mathrm{L}$ quantification was performed using a mixed isotopic dilution standard of nonane-d20, decane-d22, and dodecane-d26. The one sigma error associated with each value was $\pm 20 \%$.

High Pressure Liquid Chromatography (HPLC) was used for modifier measurements. Aqueous samples were prepared for analysis by liquid/liquid extraction.

The offgas from the runs was collected on activated carbon passive sampling tubes to adsorb any organics given off during the process. All carbon tubes were prepared by Process Technology Program (PTP) personnel and then the prepared samples were analyzed by AD personnel. Each activated carbon passive sampling tube consists of two activated carbon beds. The "front" bed, closest to the sampling point, is surrounded by glass wool, and the "back" bed, approximately half as much activated carbon as the "front", is between glass wool and a foam filter. First, the tubes are "cracked" by breaking off the end of the tube to allow extraction of the activated carbon. Cracking involves scoring the tubes using a tungsten carbide blade to facilitate a clean break. After breaking the tube, the carbon is extracted with a combined technique. Initially, the glass wool is removed with a metal hooking device and placed into the appropriate vial. Then most of 
the front carbon bed will flow freely from the tube and can be poured into the appropriately labeled vial. However, in some cases, the metal hook is required to free the carbon from the glass wool previously separating the two beds. The dividing glass wool is then pulled from the tube and placed into the same preparation vial. For desorption purposes, both sets of glass wool and the front carbon bed are all placed into the "front" vial. The remaining carbon bed and any foam filters at the back of the tube are then extracted in a similar manner and placed into the "back" vial.

After all the tubes are "cracked" and the carbon is extracted, each vial is desorbed. Desorption is necessary to remove all organics from the activated carbon into a solvent for analysis. Carbon disulfide was the solvent used for every sample analyzed in accordance with the National Institute for Occupational Safety and Health (NIOSH) method 1501. Eight milliliters of carbon disulfide were added to each "front" vial, and two milliliters were added to each "back" vial. The added solvent volume for each vial was based on prescribed addition amounts for the mass of activated carbon in each bed. After adding the carbon disulfide, each vial was slightly shaken and then allowed to sit for at least thirty minutes prior to analysis (again, according to NIOSH method 1501). To perform the analysis, an aliquot of each sample of approximately one milliliter is removed from the sample vial and placed into an appropriately labeled autosampler vial.

The sludge simulant was analyzed by the PSAL and AD. The PSAL determined the chemical composition (both elemental and anions), total and dissolved solids, calcined solids, density, and $\mathrm{pH}$. To determine the elemental composition of the sludge simulant, duplicate samples of the simulant were calcined at $1100{ }^{\circ} \mathrm{C}$ and then dissolved using $\mathrm{Na}_{2} \mathrm{O}_{2} / \mathrm{NaOH}$ and lithium metaborate $\left(\mathrm{Li}_{2} \mathrm{~B}_{4} \mathrm{O}_{7} / \mathrm{LiNO}_{3}\right)$ fusions. The dissolved sludges were analyzed using Inductively Coupled Plasma - Atomic Emission Spectroscopy (ICP-AES) to determine the concentration of each cation. For the anion analyses, sludge preparation involved weighted dilution of the two samples before introduction into the Ion Chromatograph (IC). The total and dissolved solids were measured by the PSAL on two aliquots, and the insoluble and soluble solids fractions were calculated from the results. Rheology of this type of sludge simulant had been previously performed and, therefore, was not repeated in this series of testing [5].

$\mathrm{AD}$ analyzed the sludge simulant to determine the total inorganic carbon (TIC) for input to the acid addition calculation. The Immobilization Technology Section (ITS) Acid Demand TIC method was performed on three samples according to procedure L16.1, ADS-1209, with one of the samples diluted 20:1 to try to match the nominal TIC operating region.

The SRAT products from all runs were analyzed by the PSAL and PTP. A complete analysis (similar to what was done for the SRAT receipt sample) was performed on the SRAT products. This allowed for comparison to the sludge-only SRAT product and to the coupled feed SRAT product from earlier incorporation strategies.

Gases were monitored during the runs using a high-speed Agilent model 3000 micro gas chromatograph (GC) to provide insight into the reactions occurring during processing and to measure hydrogen generation. Helium was used as a purge gas tracer. Calibration checks were performed before and after each run.

The GC is self-contained and is designed specifically for fast and accurate analysis. The GCs have five main components. The first is the carrier gas (argon for this testing) to transport the sample through the MolSieve 5A PLOT (Channel A) and PLOT Q (Channel B) columns. The second is the injector, which introduces a measured amount of sample into the inlet of the analytical columns where it is separated. Injection time is 50 milliseconds for the Channel A 
gases (helium, hydrogen, nitrogen, oxygen, nitric oxide and carbon monoxide) and 100 milliseconds for the Channel B gases (carbon dioxide and nitrous oxide). The third component is the column, which is capillary tubing coated or packed with a chemical substance known as the stationary phase that preferentially attracts the sample components. As a result, components separate as they pass through the column based on their solubility. Since solubility is affected by temperature, column temperature is controlled during the run. The Channel A column is set at 60 ${ }^{\circ} \mathrm{C}$, while the Channel $\mathrm{B}$ column is set at $70{ }^{\circ} \mathrm{C}$. The fourth component is a micro-machine thermo conductivity detector. The solid state detector monitors the carrier and senses a change in its composition when a component in the sample elutes from the column. The fifth component is the data system, Cerity. Its main purpose is to generate both qualitative and quantitative data. It provides a visual recording of the detector output and an area count of the detector response. The detector response is used to identify the sample composition and measure the amount of each component by comparing the area counts of the sample to the analysis of known calibration standards. A sample was taken every 4 minutes.

\subsection{Isopar Accumulation}

Tests were performed using a blend of SRAT products from previous Sludge Batch 6 (SB6) testing (SB6-25, SB6-28, and SB6-30) to determine if the Isopar ${ }^{\circledR}$ L accumulates in the SRAT vessel at a temperature lower than the standard operating temperature. A temperature of $92{ }^{\circ} \mathrm{C}( \pm$ $2{ }^{\circ} \mathrm{C}$ ) was used for these tests.

\subsubsection{Equipment}

4L SRAT vessels were assembled with the same precautions as the partitioning study and loaded with the same amount of the blended SRAT products and heated to $92{ }^{\circ} \mathrm{C}$. Strip effluent and entrained organics were added in the same manner as the partitioning study over a time of five hours. Samples were taken every hour. The same analytical procedure was used as given in Section 0 (i.e. the vessel was drained then rinsed with hexane and submitted to AD). Carbon tubes were swapped out every hour.

\subsection{Next Generation Solvent Stability for DWPF CPC Conditions}

In the event that MCU solvent and strip effluent came in contact with other components, solvent stability tests were performed using boric acid strip effluent and the next generation solvent with nitric acid, formic acid and caustic sodium hydroxide, separately. The acid concentrations were $\mathrm{pH} 2$ and caustic was $\mathrm{pH}$ 12.5. The TTR also requested evaluation of the MCU solvent and strip stability with agitator oil and in a radiation field. These last two evaluations were performed by an examination of current literature on the topic.

\subsubsection{Equipment and Procedure}

The 0.6L "mini SRAT vessels" were used for testing fitted with a condenser and single carbon tube for offgas sample collection. $10 \mathrm{~g}$ of boric acid and $0.07 \mathrm{~mL}$ of MCU solvent were added batchwise to the acids and caustic. Each test was performed twice: one at boiling temperature and one at room temperature. Samples were collected in Teflon and glass bottles. All glassware was rinsed with DI water and then with hexane.

\subsection{Glass Formulation Studies}

To support programmatic objectives, the downstream impacts of the boric acid strip effluent to the glass formulation activities and melter operations were investigated. The impacts of boric acid additions to the projected Sludge Batch $7 \mathrm{~b}$ (SB7b) operating windows, potential impacts to frit production temperatures, and the potential impact of boron volatility were evaluated. It should be noted that although various boric acid molarities have been reported [8], the baseline 
flowsheet used to support this assessment was a $0.01 \mathrm{M}$ boric acid concentration. As warranted, increased levels of boric acid additions were also evaluated but these higher concentrations should be considered outside the current baseline flowsheet.

To assess the impact of the introduction of the new strip effluent on future SME acceptability decision, nominal and variation stage Measurement Acceptability Region (MAR) assessments developed by SRNL were used [9]. Per the TTR, the MAR assessments will use the most recent projections of Sludge Batch $7 \mathrm{~b}$ (SB7b) from Savannah River Remediation (SRR). Recent MAR assessments identified Frit 418 as a viable candidate for processing of SB7b. Specific items to be addressed in the MAR assessments include the following:

(1) Define and compare projected operating windows for the various potential SB7b flowsheets based on sludge-only, coupled operations, and/or the introduction of the boron acid strip effluent from life extension.

(2) Assess whether Frit 418 is robust to the potential perturbations in the flowsheet. That is, if sludge-only is being processed and then ARP and/or the new SE is introduced, will Frit 418 provide access to waste loadings (WLs) of interest? Or will a different frit be required? Can a single frit be identified to handle the possible composition differences that may be introduced into the SRAT (i.e., sludge-only processing, coupled operations, and/or introduction of the new SE feed with either flowsheet)? Or will a source of boric acid be required to trim SRAT batches in which the new strip effluent is not introduced but the frit has been designed for?

(3) Evaluate the impact of the current Frit 418 specifications on the projected operating windows. More specifically, how robust is the SB7b flowsheet to not only possible variation in the incoming waste streams (e.g., sludge-only, ARP, and/or boric acid) but do the current frit specifications need to be changed? Current vendor specifications for $\mathrm{B}_{2} \mathrm{O}_{3}$ in Frit 418 are $8 \pm 0.65 \mathrm{wt} \%$.

(4) Evaluate the impact of boron volatility in either the SME acceptability process (during conversion of the SME product to a glass which is ultimately used to obtain predicted properties) or during processing of the feed through the melter.

\subsection{Results and Discussion}

\subsection{CPC Flowsheet Demonstration for NGS}

This section presents the data obtained from the initial boric acid flow sheet studies, namely the comparison of the baseline SRAT/SME process with the same process implementing the next generation solvent.

\subsubsection{SRAT/SME Processing for Boric Acid Flowsheet Study}

In support of the catalytic hydrogen generation and melter feed rheology programs, a DWPF sludge simulant designated $\mathrm{ABC}$ Blend was prepared from three generic Clemson Environmental Technologies Laboratory (CETL) simulants [10]. The simulant had an intermediate elemental composition between typical Purex and HM wastes. The ABC simulant blend was used for the boric acid flowsheet and solvent partitioning studies. Analytical results for the calcined elements (in $\mathrm{wt} \%$ at $1100^{\circ} \mathrm{C}$ ) are given in Table 2 with additional characterization data provided in Table 3 through Table 4. 
SRNL-STI-2011-00273

Revision 0

Table 2: wt\% Calcined Elemental Composition Final Sludge

\begin{tabular}{|l|c|}
\hline & ABC Blend \\
\hline $\mathrm{Al}$ & 16.1 \\
\hline $\mathrm{Ba}$ & 0.221 \\
\hline $\mathrm{Ca}$ & 2.55 \\
\hline $\mathrm{Cr}$ & 0.163 \\
\hline $\mathrm{Cu}$ & 0.143 \\
\hline $\mathrm{Fe}$ & 21.8 \\
\hline $\mathrm{K}$ & 0.276 \\
\hline $\mathrm{Mg}$ & 1.76 \\
\hline $\mathrm{Mn}$ & 4.05 \\
\hline $\mathrm{Na}$ & 12.2 \\
\hline $\mathrm{Ni}$ & 0.998 \\
\hline $\mathrm{Pb}$ & 0.055 \\
\hline $\mathrm{Si}$ & 1.72 \\
\hline $\mathrm{Ti}$ & 0.018 \\
\hline $\mathrm{Zn}$ & 0.213 \\
\hline $\mathrm{Zr}$ & 0.628 \\
\hline
\end{tabular}

Table 3: Density and Solids Data on Blend Simulant

\begin{tabular}{|l|c|}
\hline ABC Blend Simulant & Property \\
\hline wt \% total solids & 22.8 \\
\hline wt \% insoluble solids & 16.8 \\
\hline wt \% soluble solids & 6.00 \\
\hline wt \% calcined solids & 16.0 \\
\hline Slurry Density, g/mL & 1.18 \\
\hline Supernate Density, g/mL & 1.05 \\
\hline
\end{tabular}

Table 4: Anion Data on Blend Simulant

\begin{tabular}{|l|c|}
\hline ABC Blend Simulant & mg/kg slurry \\
\hline $\mathrm{Cl}^{-}$ & 390 \\
\hline $\mathrm{F}^{-}(\mathrm{IC})$ & $<100$ \\
\hline $\mathrm{F}^{-}$(recipe) & 47 \\
\hline $\mathrm{HCO}_{2}{ }^{-}$ & 0 \\
\hline $\mathrm{NO}_{2}{ }^{-}$ & 17,950 \\
\hline $\mathrm{NO}_{3}{ }^{-}$ & 10,850 \\
\hline $\mathrm{C}_{2} \mathrm{O}_{4}{ }^{2-}$ (recipe) & 1,400 \\
\hline $\mathrm{PO}_{4}{ }^{3-}$ (by ICP-AES) & 160 \\
\hline $\mathrm{SO}_{4}{ }^{2-}$ (by IC) & 1,625 \\
\hline $\mathrm{SO}_{4}{ }^{2-}$ (by ICP-AES) & 1,350 \\
\hline Total Inorganic Carbon & 1,350 \\
\hline Supernate Inorganic Carbon & 660 \\
\hline
\end{tabular}

The baseline (NGS-1) and the boric acid run (NGS-2) experiments had 2,900 g of starting sludge before adding trim chemicals and rinse water. Mercury and noble metal concentrations were based on SB7 values. Rhodium was trimmed as a solution of $\mathrm{Rh}\left(\mathrm{NO}_{3}\right)_{3}$ containing $4.93 \mathrm{wt} \%$ rhodium. Ruthenium was added as the dry trivalent chloride salt at a purity of $41.73 \mathrm{wt} \% \mathrm{Ru}$. Palladium was trimmed as a solution of $\mathrm{Pd}\left(\mathrm{NO}_{3}\right)_{2}$ containing $15.27 \mathrm{wt} \%$ palladium. Silver was 
added as the dry nitrate salt, $\mathrm{AgNO}_{3}$. Mercury was trimmed as dry $\mathrm{HgO}$. Targets for the two experiments (NGS-1 and NGS-2) are presented in Table 5 as $\mathrm{wt} \%$ in the dried sludge solids. The NGS-1 baseline test was repeated due to an incorrect air purge setting during the experiment. The repeated test, identified as NGS-3, utilized a redesigned SRAT vessel [11]. The NGS-1 flowsheet parameters were used for the NGS-3 testing.

Table 5: Noble metals and mercury targets

\begin{tabular}{|l|c|}
\hline & NGS1/NGS2/NGS3 \\
\hline Rh, wt \% & 0.0219 \\
\hline Ru, wt \% & 0.1000 \\
\hline Hg, wt \% & 2.1598 \\
\hline Pd, wt \% & 0.0038 \\
\hline Ag, wt \% & 0.0164 \\
\hline
\end{tabular}

Two SRAT/SME cycles were performed in the 4L SRAT vessels: a baseline test (NGS-1) and a boric acid run test (NGS-2). Aside from the addition of the boric acid, both experiments were performed under similar operating conditions. To replicate the equivalent of 14,000 gallons of strip effluent, which is bounding compared to the nominal strip effluent added in the SRAT, $5,764 \mathrm{~g}$ of $0.01 \mathrm{M}$ boric acid was prepared. The SRAT simulations targeted $135 \%$ acid stoichiometry. For NGS-2, formic and nitric acids were both stoichiometrically decreased to allow for the addition of the $0.01 \mathrm{M}$ boric acid strip while maintaining the targeted redox value. For the SME cycles, Frit 418 at $36 \%$ waste loading was targeted.

Sample data were obtained for the SRAT product samples. These were combined with material balance data (Table 6). The negative value for nitrite to nitrate conversion in NGS-3 is due to ammonia formation.

Table 6: Formate and Nitrite Results in SRAT and SME Cycles

\begin{tabular}{|l|c|c|c|}
\hline Parameter & NGS-1 $^{4}$ & NGS-2 & NGS-3 \\
\hline SRAT Formate Loss, \% & 27.8 & 27.1 & 28.0 \\
\hline SRAT Nitrite Loss, \% & 100 & 100 & 100 \\
\hline $\begin{array}{l}\text { SRAT Nitrite to Nitrate Conversion, } \\
\text { molar \% }\end{array}$ & 2.7 & 7.0 & -0.6 \\
\hline SME Formate Loss, \% & 8.1 & 15.3 & 23.0 \\
\hline SME Nitrate Loss, \% & 7.7 & 17.1 & 8.2 \\
\hline
\end{tabular}

For these experiments, about 24 hours were calculated for mercury stripping based on a stripping rate of $750 \mathrm{lb}$ water/lb Hg. As can be seen in Figure 4, trends in mercury concentration over time are similar for NGS-1 and NGS-2. For NGS-1 at 35 hours, the mercury concentration appears to be much higher than NGS-2. The probable cause for this may be mercury plating onto the agitator and then coming off during the SME cycle due to the abrasiveness of the frit, sampling, or mixing. The redesigned SRAT vessel used for NGS-3 delivers a more consistent decrease in mercury over time without the problems encountered with NGS-1 and NGS-2.

\footnotetext{
${ }^{4}$ NGS-1 data provided only for information.
} 
Figure 4: Slurry mercury concentration as a function of time

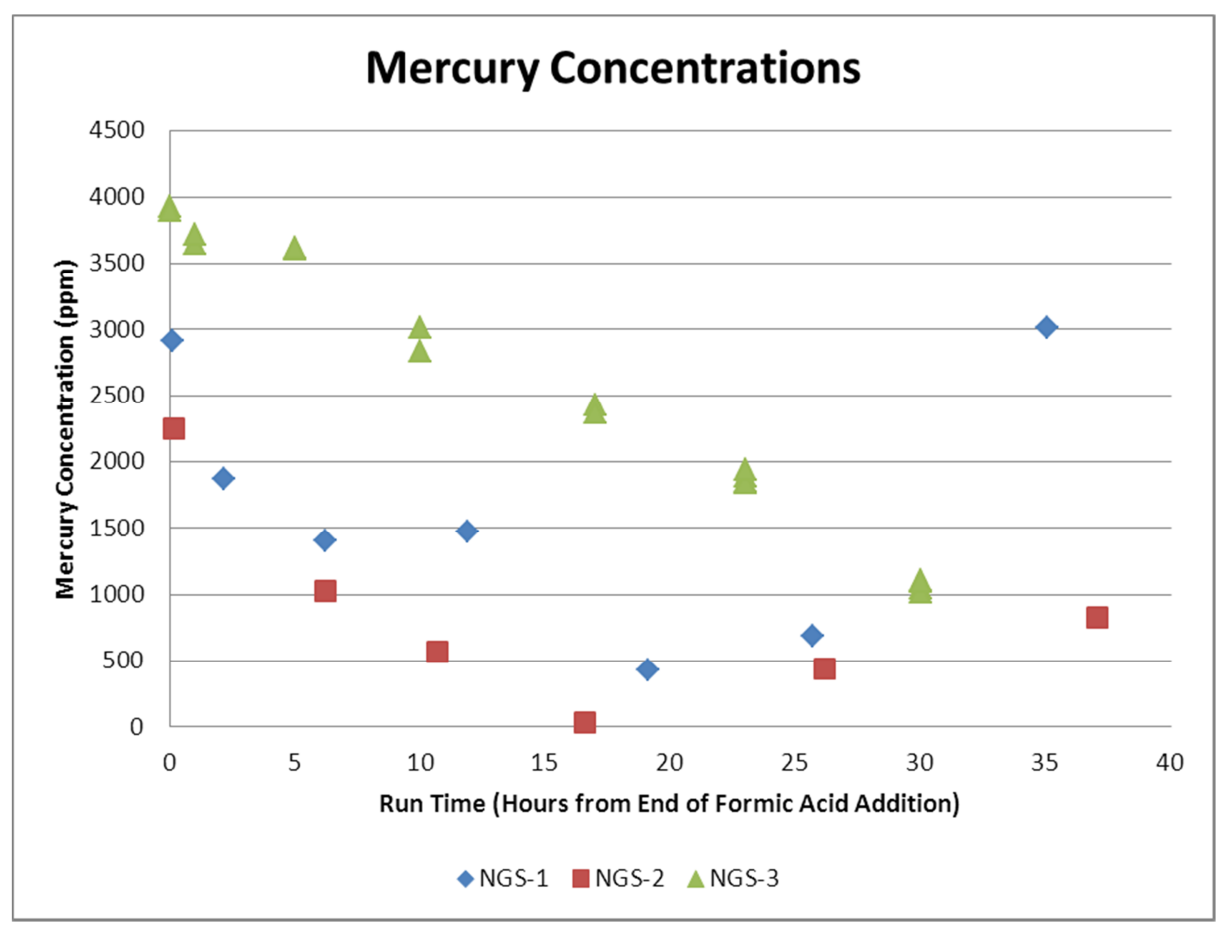

Following acid addition, samples were taken to characterize the slurry anion and supernate cation concentrations. The percentages of elements that were insoluble in the $\mathrm{ABC}$ simulant and then partially dissolved during acid addition along with $\mathrm{pH}$ are presented in Table 7 for the SRAT cycle and Table 8 for the SME cycle.

Table 7: Percentages of selected elements in supernate after acid addition

\begin{tabular}{|c|c|c|c|c|c|c|c|c|}
\hline & B & Ca & Cu & K & Mg & Mn & Na & pH \\
\hline NGS-1 & 0.0 & 83.4 & 0.2 & 105.0 & 99.3 & 78.0 & 103.0 & 7.86 \\
\hline NGS-2 & 89.2 & 87.8 & 0.1 & 116.1 & 85.0 & 68.6 & 102.0 & 7.85 \\
\hline
\end{tabular}

Table 8: Percentage of selected elements in SME product supernate

\begin{tabular}{|c|c|c|c|c|c|c|c|c|}
\hline & B & Ca & Cu & K & Mg & Mn & Na & pH \\
\hline NGS-1 & 0.0 & 80.1 & 0.3 & 70.9 & 92.4 & 77.4 & 57.5 & 6.47 \\
\hline NGS-2 & 2.3 & 79.6 & 0.0 & 65.9 & 84.0 & 68.4 & 56.5 & 6.98 \\
\hline
\end{tabular}

From this data, there appears to be little change in supernate composition, other than boron which is due to the boric acid addition in NGS-2 for the SRAT cycle. The $\mathrm{pH}$ for both experiments is similar, indicating little or no impact from the substitution of boric acid for some of the formic and nitric acids.

The total solids were measured for the SRAT and SME products, and the insoluble and soluble solids were then calculated. To complete the physical properties measurements, $\mathrm{pH}$, densities, and calcined solids were also measured. SRAT/SME product property comparisons between NGS-1 and NGS-2 show the two to be very similar with some variation in ammonium (Table 9 
and Table 10). The decrease in ammonium for NGS-2 can be attributed to less formic acid being used to account for the inclusion of boric acid.

Table 9: SRAT product slurry properties

\begin{tabular}{|l|c|c|}
\hline & NGS-1 & NGS-2 \\
\hline $\mathrm{Wt} \%$ total solids & 25.8 & 25.5 \\
\hline $\mathrm{Wt} \%$ insoluble solids & 15.0 & 14.9 \\
\hline $\mathrm{Wt} \%$ soluble solids & 10.7 & 10.7 \\
\hline $\mathrm{Wt} \%$ calcined solids & 16.3 & 16.2 \\
\hline Slurry density, g/mL & 1.18 & 1.19 \\
\hline Supernate density, g/mL & 1.086 & 1.084 \\
\hline $\mathrm{pH}$ at $25^{\circ} \mathrm{C}$ & 7.86 & 7.85 \\
\hline Fluoride, $\mathrm{mg} / \mathrm{kg}$ slurry & $<100$ & $<100$ \\
\hline Chloride, $\mathrm{mg} / \mathrm{kg}$ slurry & 862 & 830 \\
\hline Nitrite, $\mathrm{mg} / \mathrm{kg}$ slurry & $<100$ & $<100$ \\
\hline Nitrate, $\mathrm{mg} / \mathrm{kg}$ slurry & 20,800 & 20,800 \\
\hline Sulfate, $\mathrm{mg} / \mathrm{kg}$ slurry & $<100$ & $<100$ \\
\hline Formate, $\mathrm{mg} / \mathrm{kg}$ slurry & 49,050 & 48,300 \\
\hline Phosphate, $\mathrm{mg} / \mathrm{kg}$ slurry & $<100$ & $<100$ \\
\hline Ammonium, mg/L slurry & 450 & 149 \\
\hline
\end{tabular}

Table 10: SME product slurry properties

\begin{tabular}{|l|c|c|}
\hline & NGS-1 & NGS-2 \\
\hline $\mathrm{Wt} \%$ total solids & 51.9 & 52.9 \\
\hline $\mathrm{Wt} \%$ insoluble solids & 41.3 & 42.5 \\
\hline $\mathrm{Wt} \%$ soluble solids & 10.6 & 10.4 \\
\hline $\mathrm{Wt} \%$ calcined solids & 42.9 & 43.8 \\
\hline Slurry density, g/mL & 1.45 & 1.46 \\
\hline Supernate density, g/mL & 1.123 & 1.125 \\
\hline pH at $25{ }^{\circ} \mathrm{C}$ & 6.47 & 6.98 \\
\hline Fluoride, $\mathrm{mg} / \mathrm{kg}$ slurry & $<100$ & $<100$ \\
\hline Chloride, $\mathrm{mg} / \mathrm{kg}$ slurry & 799 & 770 \\
\hline Nitrite, $\mathrm{mg} / \mathrm{kg}$ slurry & $<100$ & $<100$ \\
\hline Nitrate, $\mathrm{mg} / \mathrm{kg}$ slurry & 19,050 & 17,600 \\
\hline Sulfate, $\mathrm{mg} / \mathrm{kg}$ slurry & $<100$ & $<100$ \\
\hline Formate, $\mathrm{mg} / \mathrm{kg}$ slurry & 48,000 & 45,000 \\
\hline Phosphate, $\mathrm{mg} / \mathrm{kg}$ slurry & $<100$ & $<100$ \\
\hline
\end{tabular}

\subsubsection{Rheology Data}

Flow curves of the SRAT and SME products were measured using a Haake rheometer operated in the Searle mode (rotating inner cylinder with stationary outer cylinder). Data were fit to the Bingham plastic equation (yield stress and consistency). Differences in the NGS-1 and NGS-2 yield stress and consistency for both SRAT and SME cycle slurries (Table 11) are likely attributed to differences in the wt \% total solids. The impact of solids on rheological properties is non-linear, therefore small changes in total solids can result in large changes in rheology as solids concentration reaches the DWPF processing limits. SME product rheology was tested at various wt $\%$ solids and reported in Figure 5. Both the up and down curves are presented. For insoluble solids greater than $\sim 42 \mathrm{wt} \%$, yield stress for NGS-2 begins to increase at a larger rate than for 
NGS-1. The yield stress for these SME products is higher than the design basis for the SME sample pump of $25 \mathrm{~Pa}$. This can be attributed to the total solids for NGS-1 and NGS-2 being higher than what is typically targeted in the DWPF ( $45 \mathrm{wt} \%$ ). Diluting these SME products to comparable solids amounts would likely decrease the yield stress to below the design basis. Additional testing will be performed during nonradioactive flowsheet studies during qualifications of each sludge batch.

Table 11: Rheology data for NGS-1 and NGS-2 SRAT/SME cycles

\begin{tabular}{|l|c|c|}
\hline & Yield Stress (Pa) & Consistency (cP) \\
\hline NGS-1 SRAT & 3.43 & 7.40 \\
\hline NGS-2 SRAT & 2.34 & 6.90 \\
\hline NGS-1 SME & 36.71 & 39.18 \\
\hline NGS-2 SME & 50.14 & 46.80 \\
\hline
\end{tabular}

Figure 5: NGS1 and NGS2 SME product rheology at varying insoluble solids

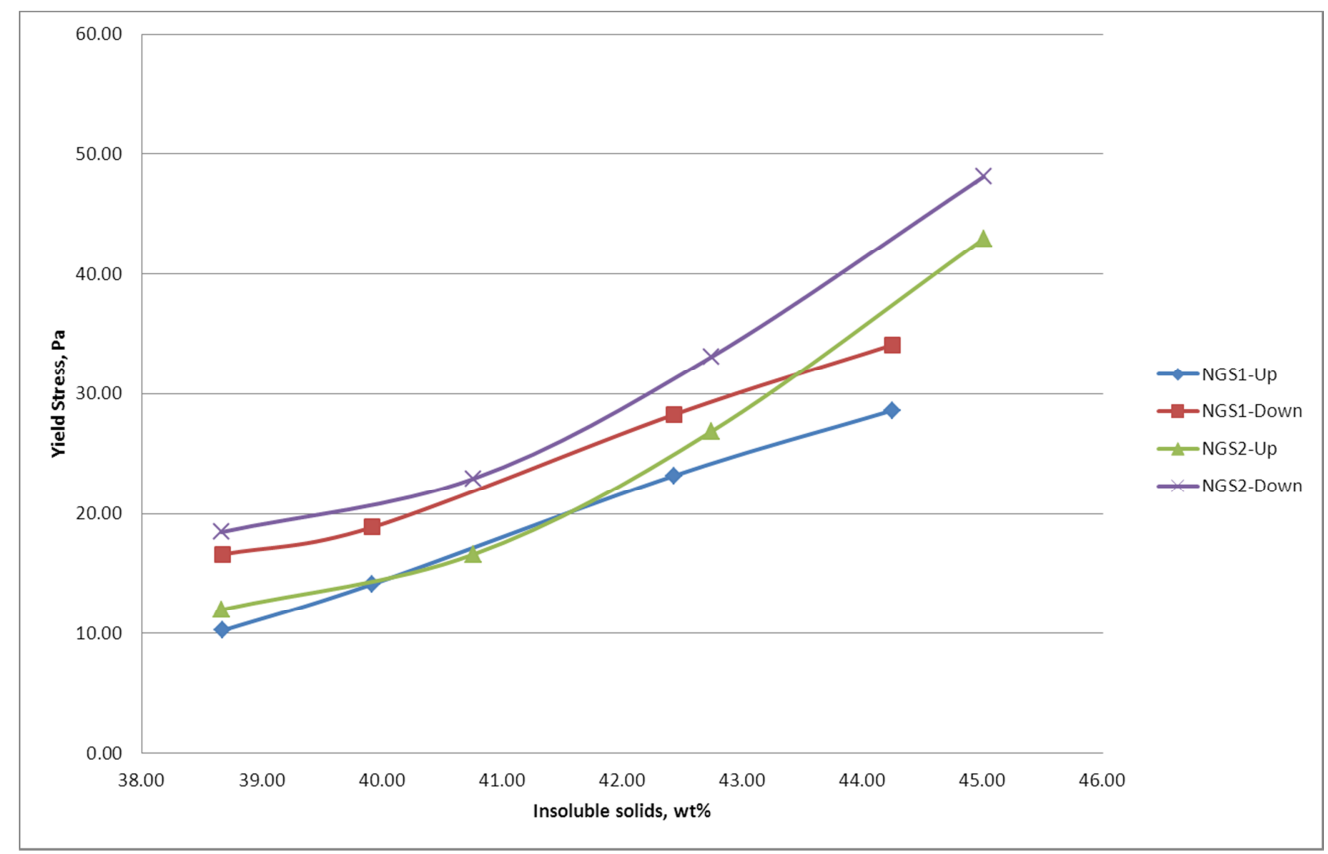

\subsubsection{Off-gas data}

Gas chromatography was used to analyze the composition of the off-gas downstream of the FAVC. Hydrogen, carbon dioxide, oxygen, nitrous oxide, and nitrogen were measured throughout the tests and are presented in Figure 6 through Figure 10 in DWPF scale, lb/hr. SRAT and SME cycle hydrogen data are given in Figure 6 and Figure 7, respectively. It is immediately apparent that more hydrogen was generated in the NGS-1 test for both cycles, perhaps resulting from poor mixing. NGS-1 was repeated and identified as NGS-3. The results of this test show hydrogen and other offgas generation consistent with NGS-2. 


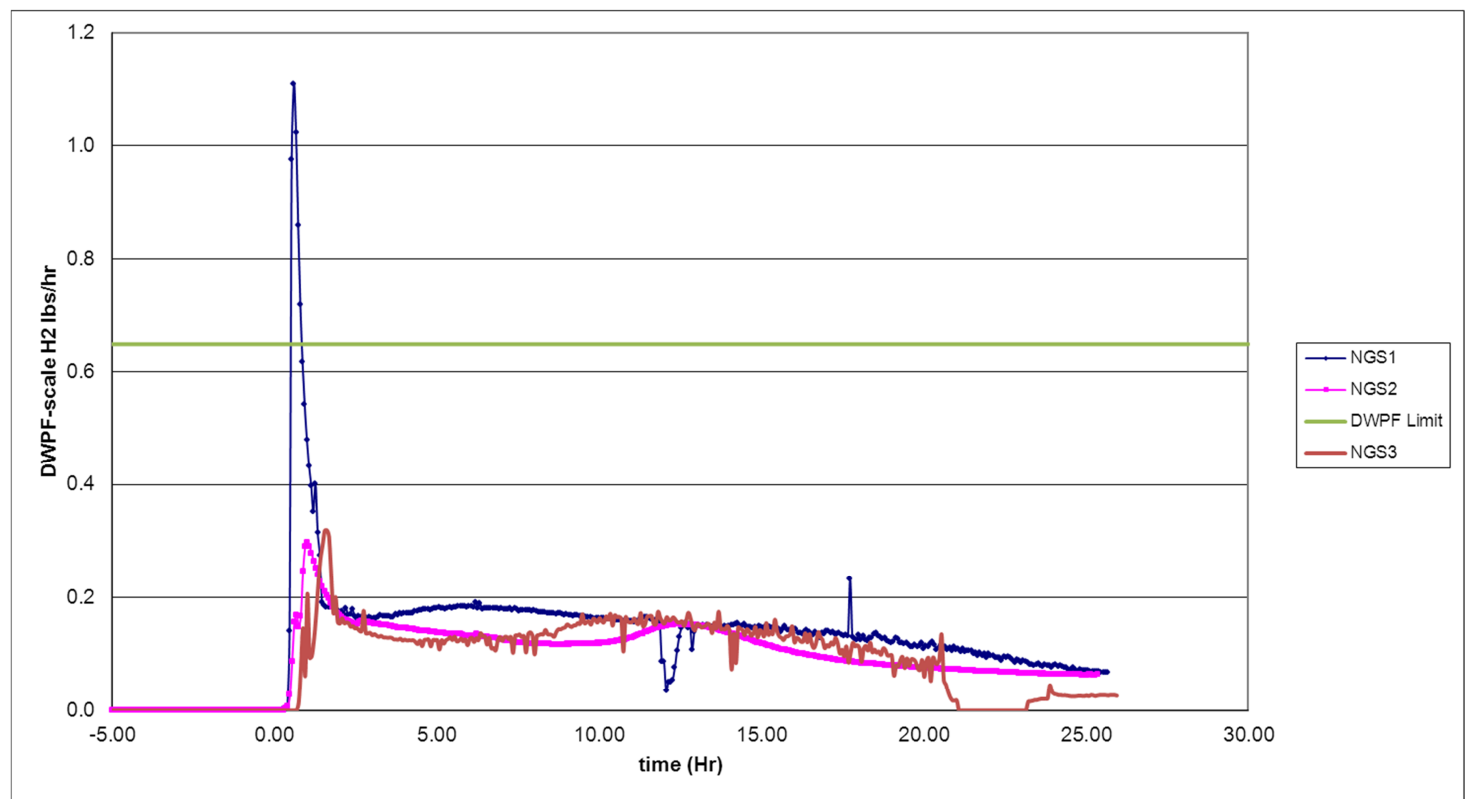

Figure 6: SRAT Cycle Hydrogen Generation, lb/hr DWPF Scale

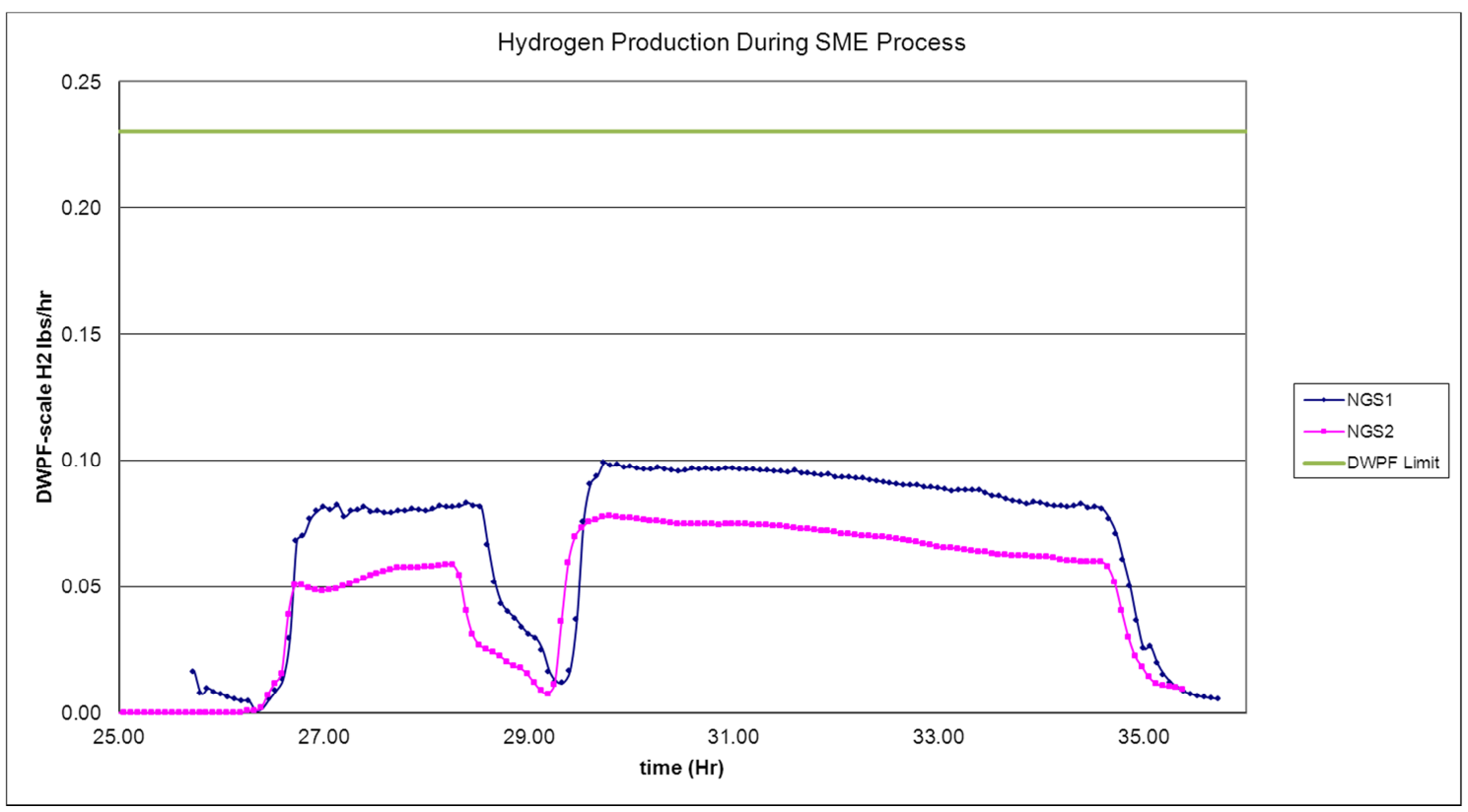

Figure 7: SME Cycle Hydrogen Generation ${ }^{5}$, lb/hr DWPF Scale

Formic acid and nitric acid amounts were decreased for NGS -2 to allow for the addition of boric acid. Table 12 also presents the stoichiometric acid calculation results for formic and nitric acid (excluding boric acid) which show a slightly decreased amount for NGS-2. The amount of acid required by the DWPF and the Koopman equations were reduced by the absolute amount to correct for the boric acid addition. The percentage impact of the reduction was larger for the DWPF equation since the original acid amount was smaller than the Koopman

${ }^{5}$ For this figure, the data representing NGS2 has been manually shifted slightly to the left to allow for a better visual comparison between the data sets. 
equation. The result is that the stoichiometric factor for the DWPF equation was slightly higher for NGS-2 than NGS-1. The difference in the stoichiometric factor is less than the error expected in the analytical results used to calculate the acid demand, and no impacts to the test results should be attributed to the small difference in acid demand.

Table 12: Stoichiometric acid calculation results, mol acid/L slurry

\begin{tabular}{|l|c|c|c|c|}
\hline & $\begin{array}{c}\text { DWPF Eqn } \\
\mathbf{m o l} / \mathbf{L}\end{array}$ & $\begin{array}{c}\text { Koopman Min. } \\
\mathbf{m o l} / \mathbf{L}\end{array}$ & $\begin{array}{c}\text { Actual addition at } \\
\mathbf{1 3 5 \%} \mathbf{m o l} / \mathbf{L}\end{array}$ & $\begin{array}{c}\text { Equivalent } \\
\text { DWPF factor }\end{array}$ \\
\hline NGS-1 & 1.12 & 1.44 & 1.95 & 174.8 \\
\hline NGS-2 & 1.04 & 1.37 & 1.85 & 177.3 \\
\hline
\end{tabular}

Off-gas data for carbon dioxide, nitrous oxide, and oxygen are given in Figure 8 through Figure 10 and show a similar trend in off-gas production for both NGS-1 and NGS-2. SRAT oxygen depletion for NGS-1 was greater than that for NGS-2 during acid addition due to an incorrect air purge setting. The air purge setting was corrected at the end of acid addition. The concentrations shown are corrected for actual flowrates used.

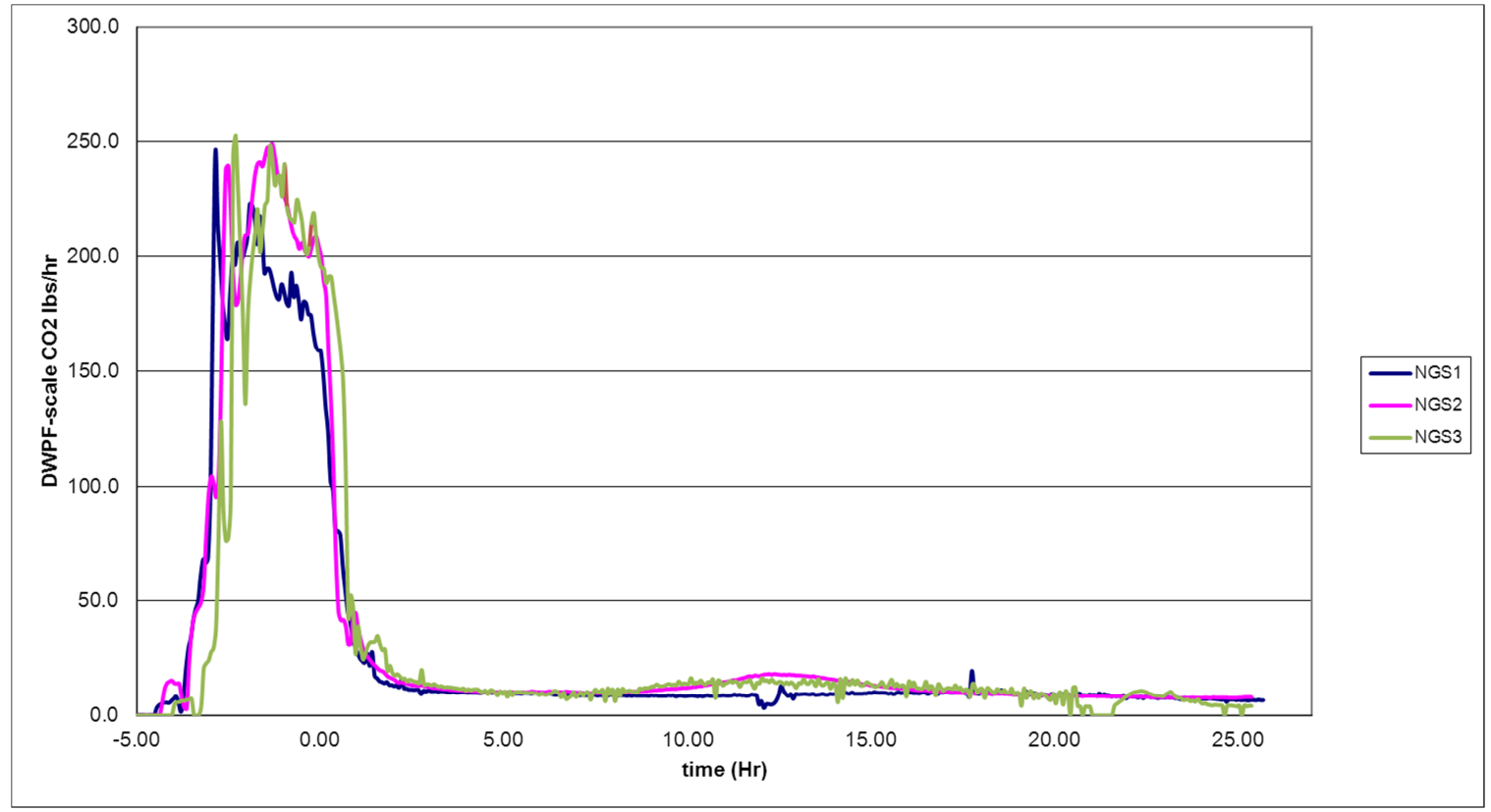

Figure 8: SRAT Cycle Carbon Dioxide Generation, lb/hr DWPF Scale 


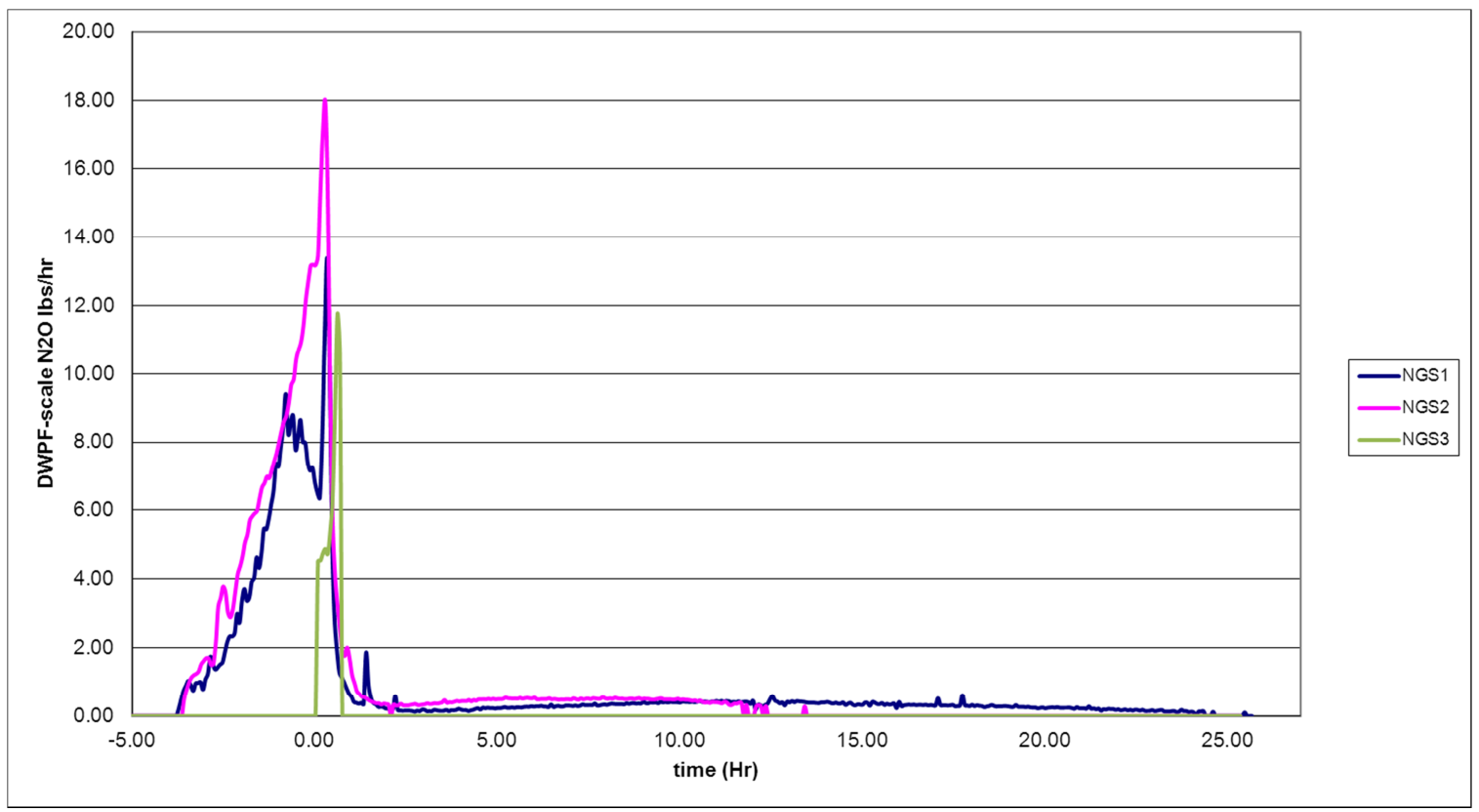

Figure 9: SRAT Cycle $\mathrm{N}_{2} \mathrm{O}$ Generation, lb/hr DWPF Scale

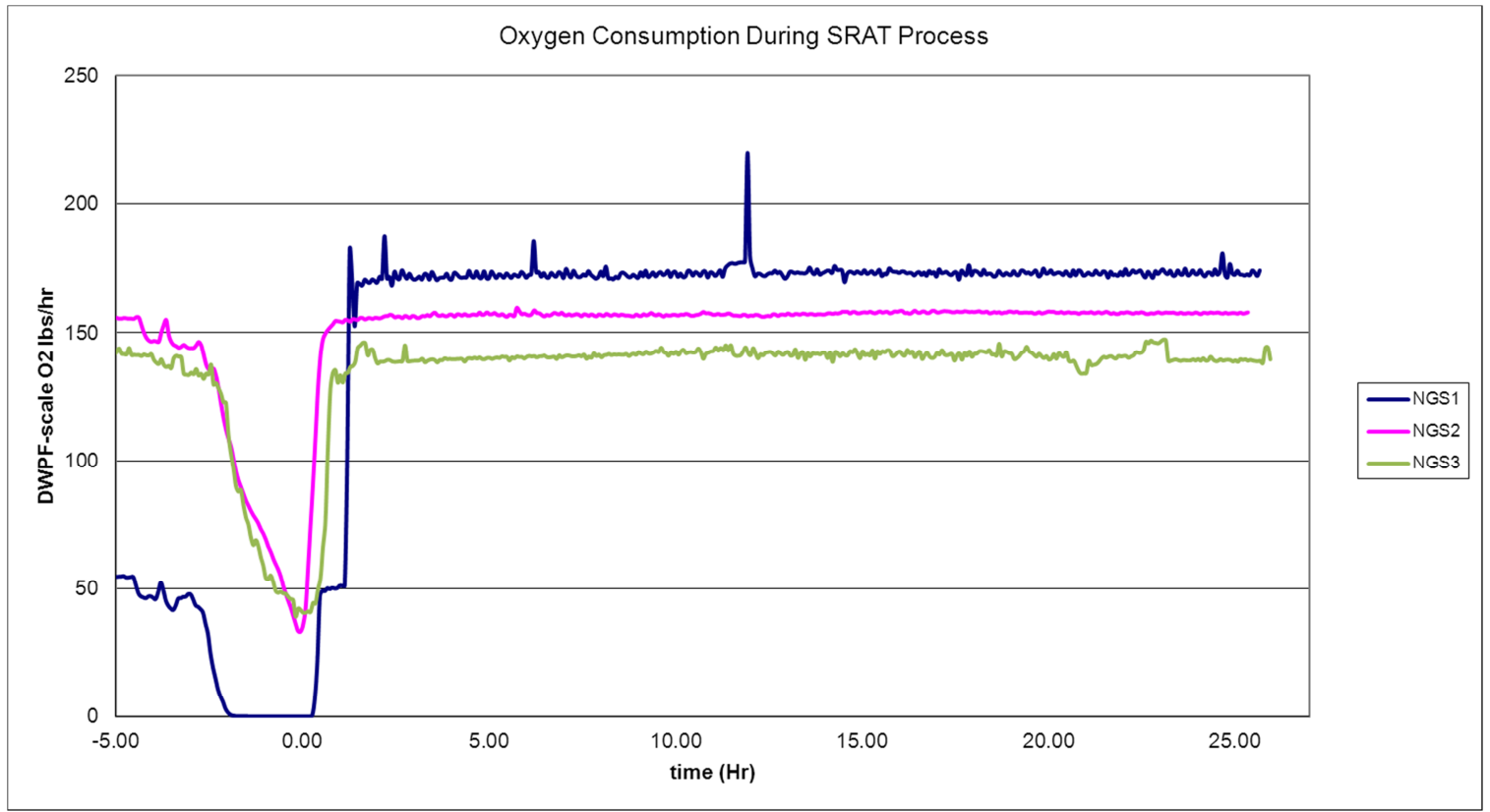

Figure 10: SRAT Cycle Oxygen Consumption, lb/hr DWPF Scale

\subsection{Next Generation Solvent Partitioning}

\subsubsection{SRAT Processing}

The SRAT cycles were performed at the ACTL in a chemical hood. Each run was started by adding the sludge simulant to the kettle and then the noble metals and mercury were added. $25^{\circ} \mathrm{C}$ Shell side temperatures for the SRAT/SME condensers were $25^{\circ} \mathrm{C}$ and $4{ }^{\circ} \mathrm{C}$ for the FAVC. Heating was initiated and $200 \mathrm{ppm}$ antifoam was added with an equal mass of water. Nitric acid was added 
first and then formic acid. After the completion of acid addition, $500 \mathrm{ppm}$ antifoam was added and the vessel was ramped to boiling. Once boiling was initiated, the SRAT contents were dewatered/concentrated to bring the sludge to the target solids concentration. Note that cesium was not added to the strip effluent during this testing.

Strip effluent addition was initiated after dewatering was completed. The target solvent level was $125 \mathrm{mg}$ solvent/kg effluent. The strip effluent boric acid was added using a Series " $\mathrm{R}$ " piston pump on a MasterFlex drive, while the entrained solvent was added using a syringe pump. The feed rate of the boric acid was set to $3.9 \mathrm{~mL} / \mathrm{min}$, while the organic addition rate was calculated and set based on the estimated time to add the aqueous stream $(0.03 \mathrm{~mL} / \mathrm{hr}$ for the first 346 minutes then $0.04 \mathrm{~mL} / \mathrm{hr}$ for the last 241 minutes). Feeding the boric acid/solvent took $\sim 10$ hours. Mixing and heating of the slurries during the SRAT cycles were not an issue. Upon conclusion of the SRAT cycle, the SRAT vessel was allowed to cool to $50^{\circ} \mathrm{C}$ and the simulant pumped out, leaving a $625 \mathrm{~mL}$ heel. No problems with foaming or processing of the slurries were evident.

\subsubsection{Organic data}

Precautions were put in place to ensure maximum recovery of the solvent. The testing protocol/equipment configuration included the following:

- All O-rings were either Teflon encapsulated or Kalrez.

- Use of grease to seal glass joints was minimized.

- Krytox fluorinated grease was used in place of silicone high vacuum grease.

- Teflon lines were used in the offgas system and MCU aqueous additions.

- All samples were collected in Teflon bottles or glass vials with Teflon cap.;

- A triple rinse of each component was incorporated to ensure that all of the MCU organic was being removed.

- System fittings were tightened to obtain an outlet flow within $5 \%$ of the target to minimize the potential for solvent loss.

- A leak check of the SRAT equipment was performed between each run.

The organic samples were divided into three primary groupings. The first set included samples of the SRAT product and condensates generated during processing. The second set included the solvent rinse solutions that were generated from rinsing the SRAT equipment to remove any organic that adhered to the equipment surfaces. The final grouping included the carbon tubes that were installed downstream of the FAVC to capture any gaseous organic species exiting the offgas system.

The first set of samples included the SRAT product, the condensate or SMECT samples collected during boric acid/solvent addition, and the FAVC samples. This set also included the MWWT sample which was pulled only after the last of the five runs. This set of samples required extraction by $\mathrm{AD}$ to determine the concentration of strip effluent organics present.

The second set of samples were prepared by rinsing equipment after the conclusion of the 5 back to back tests with hexane to extract any residual solvent remaining. This set of solvent rinse samples did not require extractions by $\mathrm{AD}$ since they already contained hexane as the rinse solvent.

All aqueous and organic samples were submitted to AD for volatile organic analysis (VOA), semivolatile organic analysis (SVOA), and HPLC analyses. Extraction of the carbon tubes with 
carbon disulfide was performed at ACTL by PTP personnel. The carbon disulfide extractant was then submitted to AD.

For the solvent partitioning tests, a total of $0.873 \mathrm{~g}$ of Isopar was used during the 5 runs. Of this, $0.81 \mathrm{~g}$ of Isopar was recovered resulting in a total mass recovery of $93 \%$. Of that amount, most $(90 \%)$ was recovered in the offgas by the carbon tubes with approximately $3 \%$ found in the MWWT sample. As mentioned earlier, the carbon tubes have two sections, a front and back. Each section was analyzed separately. Any Isopar found on the back portion would indicate the possibility that unrecoverable Isopar had exited the offgas, resulting in low mass balance. All Isopar recovered on the carbon tubes was found on the front section. These results are consistent with previous results reported by Lambert [7] who reported Isopar recovery of 94\%.

As expected, and confirmed by the analytical results, all of the Isopar exits the SRAT vessel and travels through the offgas, with a majority of it (90\%) captured on the carbon tubes.

Modifier analysis was performed by HPLC. Of the $0.275 \mathrm{~g}$ of modifier actually used in the SRAT cycles, $0.14 \mathrm{~g}$ was recovered. This resulted in a total mass recovery of $49 \%$. Of the total amount recovered, $41 \%$ was recovered from the SRAT vessel, $30 \%$ from the SMECT, and $23 \%$ in the MWWT. None of the modifier was found on the carbon tubes. In comparison to previous results [7], this data is similar with respect to partitioning: 55\% in SRAT, $29 \%$ in SMECT, and $14 \%$ in MWWT. Recovery, however, is lower than Lambert's reported recovery of $94 \%$.

From this data, we can surmise that a majority of the modifier collected in the SRAT vessel. However, this testing did not include a SME cycle. Had a SME cycle been performed, it is expected that a lower concentration of modifier would be detected in the melter feed, as SME product is subject to additional boiling and steam stripping of the modifier would ensue. This would result in a greater mass of the modifier in the SMECT.

\subsection{Isopar Accumulation}

The first step of the SRAT cycle is to heat the sludge to $93{ }^{\circ} \mathrm{C}$. At the completion of the acid additions, the sludge is heated to boiling to steam strip mercury and remove water by obtaining the proper weight percent solids. If the SRAT doesn't reach boiling temperatures, the possibility exists that Isopar could accumulate. Isopar accumulation testing was performed using SB6 to determine if the Isopar would accumulate in the SRAT at lower operating temperatures of $92{ }^{\circ} \mathrm{C}$.

Comparisons were made between the current baseline and next generation solvents. Tests were performed using 2,200 $\mathrm{g}$ of SRAT product. During the cycles, 1,300 $\mathrm{g}$ of strip effluent and $0.20 \mathrm{~mL}$ of MCU solvent were added over 5 hours. This amount is equivalent to 9,000 gallons of strip effluent, which is bounding compared to the nominal amount added to the SRAT. The first test, denoted as IA1, utilized the next generation solvent, while the second test, IA2, utilized the current MCU solvent composition. The modified SRAT setup, as depicted in Figure 2 was used. Carbon tubes were exchanged every hour during the five hour cycle to collect any offgas samples. The same rinse and analytical procedures used for the partitioning tests were used.

\subsubsection{Organic data}

The organic samples were divided into three primary groupings. The first set included samples of the SRAT product and condensates generated during processing. The second set included the solvent rinse solutions that were generated from rinsing the SRAT equipment to remove any organic that adhered to the equipment surfaces. The final grouping included the carbon tubes that 
were installed downstream of the FAVC to capture any gaseous organic species exiting the offgas system.

The first set of samples included the SRAT product, the condensate or SMECT samples collected during MCU addition, and the FAVC samples. This set also included the MWWT sample which was pulled only after the last of the five runs. This set of samples required extraction by AD to determine the concentration of MCU organics present.

The second set samples were prepared by rinsing the drained equipment with hexane to extract any residual solvent remaining. This set of solvent rinse samples did not require extractions by AD since they already contained hexane as the rinse solvent.

All aqueous and organic samples were submitted to AD for VOA, SVOA, and HPLC analyses. Extraction of the carbon tubes with carbon disulfide was performed at ACTL by PTP personnel. The carbon disulfide extractant was then submitted to AD.

For IA1 (new solvent), $0.084 \mathrm{~g}$ of Isopar was used. Of that, $0.074 \mathrm{~g}$ was recovered, resulting in a total mass recovery of $85 \%$. For IA2 (current solvent), $0.110 \mathrm{~g}$ of Isopar was used. Of that, $0.099 \mathrm{~g}$ was recovered, resulting in a total mass recovery of $90 \%$. $\mathrm{t}$ can be concluded that, even at a lower operating temperature of $92^{\circ} \mathrm{C}$, the majority of Isopar was found on the carbon tubes during both runs, similar to the partitioning study. All of the Isopar for IA1 was recovered in the offgas on the carbon tubes. The only difference between the comparison of the two solvents is the recovery of Isopar in the FAVC for the current solvent.

Modifier recovery was also evaluated. For IA1 (new solvent), $0.022 \mathrm{~g}$ of modifier was used. Of that, $0.015 \mathrm{~g}$ was recovered, resulting in a total mass recovery of $67 \%$. For IA2, $0.047 \mathrm{~g}$ of modifier was used. Of that, $0.032 \mathrm{~g}$ was recovered, resulting in a total mass recovery of $69 \%$. Table 13 details the locations of the modifier recovery.

Table 13: Modifier recovery

\begin{tabular}{|l|c|c|}
\hline & $\begin{array}{c}\text { IA1 - Modifier } \\
\text { recovery \% }\end{array}$ & $\begin{array}{c}\text { IA2 - Modifier } \\
\text { recovery \% }\end{array}$ \\
\hline SRAT vessel & 93 & 94 \\
\hline SRAT Condenser & 1 & 1 \\
\hline MWWT & 5 & 4 \\
\hline FAVC & 0 & 0 \\
\hline $\begin{array}{l}\text { Total mass } \\
\text { recovered }\end{array}$ & 67 & 69 \\
\hline
\end{tabular}

As can be seen in Table 13, almost all the modifier remains in the SRAT vessel. Given the low vapor pressure of modifier, this result was expected. Comparison of the two SRAT cycles shows they are nearly identical in both the amount recovered and location of the recoveries. The data indicates the modifier is more susceptible to carryover during boiling.

\subsection{Next Generation Solvent Stability for DWPF CPC Conditions}

During processing at DWPF, the possibility exists for contact of the MCU solvent with other components. To this end, the stability of the strip effluent and solvent was determined by mixing both with nitric acid, formic acid, sludge simulant, agitator oil, and sodium hydroxide at both boiling and room temperatures (r.t.). It was also requested that radiation stability tests be performed on the next generation solvent. 
Solvent stability tests were performed using a 1L SRAT vessel fitted with a condenser and single carbon tube. Room temperature and boiling tests were conducted side-by-side. $200 \mathrm{~mL}$ of each component (acid, caustic, and simulant) were combined with $10 \mathrm{~g} 0.01 \mathrm{M}$ boric acid and $0.07 \mathrm{~mL}$ of the next generation solvent. Sufficient concentrations were used to allow for any possible reactions to occur and do not reflect current SRAT processing. At the conclusion of each test, samples were collected and all glassware rinsed with water and then hexane, as detailed in section 3.2.2.

\subsubsection{Organic data}

Table 14 through Table 17 detail the analytical data for the next generation solvent stability and strip effluent when reacted with nitric acid, formic acid, caustic, and simulant, respectively. In all room temperature cases, Isopar recovery was less than $27 \%$ while modifier recovery was about the same for boiling vs. room temperature reactions. Though the percentage of Isopar and modifier recovered are listed for each test, the purpose of these experiments was to determine any degradation products that may have resulted during these reactions. The analyses of the condensates, SRAT products, and carbon tubes revealed that there were no identified analytes that resulted from decomposition of the organic solvent at either room temperature or boiling.

Table 14: Solvent stability with nitric acid

\begin{tabular}{|l|c|c|c|c|}
\hline & \multicolumn{2}{|c|}{ Nitric acid, r.t. } & \multicolumn{2}{c|}{ Nitric acid, boiling } \\
\hline Solvent used (g) & \multicolumn{2}{|c|}{0.049} & \multicolumn{2}{c|}{0.053} \\
\hline Isopar recovered (\%) & \multicolumn{2}{|c|}{22} & \multicolumn{2}{c|}{66} \\
\hline Modifier recovered (\%) & \multicolumn{2}{|c|}{51} & Modifier \\
\hline & $\begin{array}{c}\text { Isopar } \\
\text { recovered (\%) }\end{array}$ & $\begin{array}{c}\text { Isopar } \\
\text { recovered (\%) } \\
\text { recovered (\%) }\end{array}$ & $\begin{array}{c}\text { Modifier } \\
\text { recovered (\%) }\end{array}$ \\
\hline SRAT vessel & 28 & 100 & 0 & 13 \\
\hline SRAT condenser & 0 & 0 & 50 & 89 \\
\hline Carbon Tube & 72 & 0 & 50 & 0 \\
\hline
\end{tabular}

Table 15: Solvent stability with formic acid

\begin{tabular}{|l|c|c|c|c|}
\hline & \multicolumn{2}{|c|}{ Formic acid, r.t. } & \multicolumn{2}{c|}{ Formic acid, boiling } \\
\hline Solvent used (g) & \multicolumn{2}{|c|}{0.057} & \multicolumn{2}{c|}{0.061} \\
\hline Isopar recovered (\%) & \multicolumn{2}{|c|}{22} & \multicolumn{2}{c|}{66} \\
\hline Modifier recovered (\%) & \multicolumn{2}{|c|}{69} & \multicolumn{2}{c|}{59} \\
\hline & $\begin{array}{c}\text { Isopar } \\
\text { recovered (\%) }\end{array}$ & $\begin{array}{c}\text { Modifier } \\
\text { recovered (\%) }\end{array}$ & $\begin{array}{c}\text { Isopar } \\
\text { recovered (\%) }\end{array}$ & $\begin{array}{c}\text { Modifier } \\
\text { recovered (\%) }\end{array}$ \\
\hline SRAT vessel & 43 & 100 & 4 & 28 \\
\hline SRAT condenser & 0 & 0 & 61 & 73 \\
\hline Carbon Tube & 57 & 0 & 35 & 0 \\
\hline
\end{tabular}


SRNL-STI-2011-00273

Revision 0

Table 16: Solvent stability with caustic

\begin{tabular}{|c|c|c|c|c|}
\hline & \multicolumn{2}{|c|}{ Caustic, r.t. } & \multicolumn{2}{|c|}{ Caustic, boiling } \\
\hline Solvent used (g) & \multicolumn{2}{|c|}{0.058} & \multicolumn{2}{|c|}{0.056} \\
\hline Isopar recovered (\%) & \multicolumn{2}{|c|}{17} & \multicolumn{2}{|c|}{75} \\
\hline Modifier recovered (\%) & \multicolumn{2}{|c|}{63} & \multicolumn{2}{|c|}{60} \\
\hline & $\begin{array}{c}\text { Isopar } \\
\text { recovered }(\%)\end{array}$ & $\begin{array}{c}\text { Modifier } \\
\text { recovered (\%) }\end{array}$ & $\begin{array}{c}\text { Isopar } \\
\text { recovered (\%) }\end{array}$ & $\begin{array}{c}\text { Modifier } \\
\text { recovered }(\%)\end{array}$ \\
\hline SRAT vessel & 16 & 100 & 0 & 60 \\
\hline SRAT condenser & 16 & 0 & 61 & 40 \\
\hline Carbon Tube & 69 & 0 & 39 & 0 \\
\hline
\end{tabular}

Table 17: Solvent stability with simulant

\begin{tabular}{|c|c|c|c|c|}
\hline & \multicolumn{2}{|c|}{ Simulant, r.t. } & \multicolumn{2}{|c|}{ Simulant, boiling } \\
\hline Solvent used (g) & \multicolumn{2}{|c|}{0.061} & \multicolumn{2}{|c|}{0.064} \\
\hline Isopar recovered (\%) & \multicolumn{2}{|c|}{27} & \multicolumn{2}{|c|}{72} \\
\hline Modifier recovered $(\%)$ & \multicolumn{2}{|c|}{47} & \multicolumn{2}{|c|}{46} \\
\hline & $\begin{array}{c}\text { Isopar } \\
\text { recovered }(\%)\end{array}$ & $\begin{array}{c}\text { Modifier } \\
\text { recovered }(\%)\end{array}$ & $\begin{array}{c}\text { Isopar } \\
\text { recovered }(\%)\end{array}$ & $\begin{array}{c}\text { Modifier } \\
\text { recovered (\%) }\end{array}$ \\
\hline SRAT vessel & 39 & 100 & 0 & 85 \\
\hline SRAT condenser & 22 & 0 & 56 & 15 \\
\hline Carbon Tube & 39 & 0 & 44 & 0 \\
\hline
\end{tabular}

No experimental testing was performed to determine the solvent stability with agitator oil. Any analytical data that resulted from reacting boric acid and organic solvent with agitator oil would have been unreliable, as the boiling oil would result in the carbon tubes being saturated with hydrocarbons. Instead, a review of the current literature was conducted. Boric acid is being evaluated by DOE as an additive to oils to decrease their viscosity [12]. As such, there is no chemical reaction that would cause any decomposition of the oil or boric acid. No chemical reaction would occur upon adding the organic solvent with agitator oil. Both are made up of hydrocarbons, and combining the two would only result in mixing.

\subsubsection{Next generation solvent radiation stability}

A review of the literature was completed to determine the state of knowledge on the radiation stability of the next generation solvent and reported separately [1]. The following is a summary from that report. The review determined that the radiation stability of the main components of the NG-CSSX solvent system, Isopar ${ }^{\circledR}$ L and the Modifier Cs-7SB have been well studied. However, the two new components of the solvent system, the calixarene-crown ether designated MaxCalix and the LIX ${ }^{\circledR} 79$ guanidine suppressor, have not been studied for radiation stability, although some work is proceeding at Oak Ridge National Laboratory for this purpose. Limited testing with actual radioactive waste samples at the Savannah River Site (SRS) indicate the performance of the new NG-CSSX solvent system remains fairly stable with up to 2 Mrad radiation exposures. Additional performance testing with the new solvent system is planned in the near future to look at the loss of the guanidine suppressor versus received dose. However, the program has no near term plans to study the radiation stability of MaxCalix. The expectation is that due to the structural similarity between BOBCalixC6 and MaxCalix, the radiation stability can be reasonably assumed to be similar also. 
Due to the insufficient data on radiation stability for two new components, a worst case calculation was performed assuming all of the hydrogen atoms from the MaxCalix and the guanidine suppressor form hydrogen in the SRAT. The molecular formula for MaxCalix is $\mathrm{C}_{62} \mathrm{H}_{82} \mathrm{O}_{8}$ and $\mathrm{C}_{26} \mathrm{H}_{51} \mathrm{~N}_{3}$ for the suppressor.

Assuming 40,000 L of strip effluent per SRAT batch with an organic solvent concentration of 125 $\mathrm{mg} / \mathrm{L}$, a total of $5000 \mathrm{~g}(6.04 \mathrm{~L})$ of solvent will enter each SRAT batch. The MaxCalix is present at a concentration of $0.05 \mathrm{M}$ in the solvent and contains potentially 41 moles of $\mathrm{H}_{2}$ per mole of MaxCalix. Although the MaxCalix will likely not significantly degrade during typical SRAT/SME operation, complete degradation of the MaxCalix was assumed for this calucation resulting in a maximum of 12 moles of $\mathrm{H}_{2}$ that could be released per SRAT batch from the MaxCalix. The guanidine is present at a concentration of $0.003 \mathrm{M}$ in the solvent and contains potentially 25.5 moles $\mathrm{H}_{2}$ per mole of guanidine. Assuming complete degradation of the guanidine, 0.45 moles of $\mathrm{H}_{2}$ could be released per SRAT batch.

Moles of $\mathrm{H}_{2}$ per SRAT batch from MaxCalix $(0.05$ moles $/ \mathrm{L})(6.04 \mathrm{~L})\left(41\right.$ moles $\mathrm{H}_{2} /$ mole of MaxCalix $)=12.38$ moles $\mathrm{H}_{2}$

Moles of $\mathrm{H}_{2}$ per SRAT batch from guanidine

$(0.003$ moles $/ \mathrm{L})(6.04 \mathrm{~L})\left(25.5\right.$ moles $\mathrm{H}_{2} /$ mole of MaxCalix $)=0.46$ moles $\mathrm{H}_{2}$

Assuming all the hydrogen from the MaxCalix and guanidine is released in 1 hour (even though it would actually occur much slower) and a SRAT air purge rate of $230 \mathrm{scfm}$, the volume percent hydrogen in the SRAT from the degradation of MaxCalix and guanidine would be $0.07 \%$. This is far below the $1 \mathrm{vol} \%$ lower flammability limit for hydrogen.

\subsection{Glass Formulation Studies}

The downstream impacts of the boric acid strip effluent to the glass formulation activities and melter operations were considered. A separate report has been issued detailing these results, and a brief summary of those results are provided in this section [4].

The results of the paper study assessment indicate that Frit 418 and Frit 418-7D are robust to the implementation of the $0.01 \mathrm{M}$ boric acid SE into the SB7b flowsheet (sludge-only or ARP-added). More specifically, the projected operating windows for the nominal SB7b projections remain essentially constant (i.e., $25-43$ or $25-44 \%$ waste loading (WL)) regardless of the flowsheet options (sludge-only, ARP added, and/or the presence of the new SE). These results indicate that even if SE is not transferred to the Sludge Receipt and Adjustment Tank (SRAT), there would be no need to add boric acid (from a trim tank) to compositionally compensate for the absence of the boric acid SE in either a sludge-only or ARP-added SB7b flowsheet.

With respect to boron volatility, the Measurement Acceptability Region (MAR) assessments also suggest that Slurry Mix Evaporator (SME) acceptability decisions would not be different assuming either $100 \%$ of the boron from the SE were retained or volatilized. More specifically, the $0.84 \mathrm{wt} \%$ boron in the SE is so minor that its presence in the SME analysis does not influence SME acceptability decisions. In fact, using the $100 \%$ retention and $100 \%$ volatilization composition projections, only minor differences in the predicted properties of the glass product occur with all of the glasses being acceptable over a WL interval of $32-42 \%$.

Based on the $0.01 \mathrm{M}$ boric acid flowsheet, there is very little difference between Frit 418 and Frit 418-7D (a frit that was compositionally altered to account for the $0.84 \mathrm{wt} \%$ boric acid in the SE) with respect to melt temperature. In fact, when one evaluates the composition of Frit 418-7D, it 
lies within the current Frit 418 vendor specifications and therefore could have been produced by the vendor targeting the nominal composition of Frit 418.

\subsection{Conclusions}

A series of four experiments have been performed: flowsheet testing, solvent partitioning, Isopar accumulation, and solvent stability. Paper studies and literature reviews were conducted for glass formulation studies and radiation stability of the solvent. The following conclusions have been drawn:

- $\quad$ Flowsheet testing

- No significant negative impacts to process chemistry were observed from the addition of $0.01 \mathrm{M}$ boric acid strip effluent when an equivalent amount of nitric and formic acids were deducted from the normal acid addition.

- Off-gas data for NGS-2 and NGS-3 indicate that the addition of the strip effluent containing $0.01 \mathrm{M}$ boric acid did not result in excessive hydrogen gas generation.

- SRAT/SME product $\mathrm{pH}$ and dissolved metal content are similar.

- At wt $\%$ insoluble solids greater than $42 \%$, yield stress for NGS-2 increases more rapidly than that of NGS-1.

- Solvent partitioning

- $93 \%$ of Isopar ${ }^{\circledR} \mathrm{L}$ was recovered.

- Most (90\%) of the Isopar ${ }^{\circledR} \mathrm{L}$ was in the offgas system on the carbon tubes.

- $67 \%$ of the modifier was recovered.

- Of the total modifier recovered, $41 \%$ was recovered from the SRAT vessel, $30 \%$ from the SMECT, and $23 \%$ in the MWWT.

- None of the modifier was found on the carbon tubes.

- Partitioning of the NGS solvent was similar to the current baseline solvent.

- Isopar accumulation

- For IA1 (new solvent) Isopar ${ }^{\circledR} \mathrm{L}$ total mass recovery was $85 \%$.

- For IA2 (current solvent) Isopar ${ }^{\circledR}$ L total mass recovery was $90 \%$.

- All Isopar ${ }^{\circledR}$ L was found on the carbon tubes except for $18 \%$ recovery of Isopar ${ }^{\circledR}$ $\mathrm{L}$ in the FAVC for the current solvent.

- For IA1 modifier total mass recovery was $67 \%$.

- For IA2, modifier total mass recovery was $69 \%$.

- For both solvents, almost all $(\sim 94 \%)$ of the modifier remained in the SRAT vessel.

- Solvent stability

- In all room temperature cases, Isopar recovery was less than $25 \%$.

- Modifier recovery was about the same for boiling vs. room temperature reactions.

- Analyses of the condensates, SRAT products, and carbon tubes revealed that there were no analytes that resulted from decomposition of the organic solvent at either room temperature or boiling.

- Radiation stability

$0 \quad$ Literature review and paper study was performed [1].

- Results show that there is no significant decomposition of the solvent components when subjected to a radiation field.

- Glass formulation

○ This work has been reported in a separate document [4].

- The results of the paper study assessment indicate that Frit 418 and Frit 418-7D are robust to the implementation of the $0.01 \mathrm{M}$ boric acid SE into the SB7b flowsheet. 
- Results indicate that even if SE is not transferred to the SRAT, there would be no need to add boric acid (from a trim tank) to compositionally compensate for the absence of the boric acid SE in either a sludge-only or ARP-added SB7b flowsheet. This is coupled with the fact that the $\mathrm{B}_{2} \mathrm{O}_{3}$ concentration in the Frit $418(8 \mathrm{wt} \%)$ is the lowest $\mathrm{B}_{2} \mathrm{O}_{3}$ concentration (in frit) that DWPF is expected to process. With higher $\mathrm{B}_{2} \mathrm{O}_{3}$ containing frits, the amount of boron from the $\mathrm{SE}$ as a percentage of the boron in the frit becomes more negligible.

\subsection{Recommendations}

Through the work performed on these tasks and paper studies, there is no apparent difference in behavior between the current baseline solvent and the next generation solvent in DWPF processing. Although testing shows no accumulation of Isopar ${ }^{\circledR}$ L using the 4L SRAT vessels, the impact of scaling on the results of the accumulation study is uncertain. SRNL recommends investigating the effect of surface area to volume ratio of the SRAT on Isopar ${ }^{\circledR}$ L accumulation and the temperature at which it begins to accumulate.

SRNL recommends that the amount of nitric and formic acid added to each SRAT batch be reduced to account for the boric acid expected to be added during strip effluent addition. 
SRNL-STI-2011-00273

Revision 0

\subsection{References}

1. M.S. Hay, "Literature Review of the Radiation Stability of the Next-Generation CausticSide Solvent Extraction System (NG-CSSX)," Savannah River National Laboratory, Aiken, SC, SRNL-L3100-2011-00067.

2. J.M. Bricker, "Testing for ARP/MCU Life Extenstion Project," HLW-DWPF-TTR-20100045 .

3. J.D. Newell and D.K. Peeler, "Task Technical and Quality Assurance Plan for Evaluation of DWPF Impacts of Boric Acid Use in Cesium Strip for SWPF and MCU," Savannah River National Laboratory, Aiken, SC, SRNL-RP-2010-00172.

4. D.K. Peeler and T.B. Edwards, "The Impact of the MCU Life Extension Solvent on DWPF Glass Formulation Efforts," Savannah River National Laboratory, Aiken, SC, SRNL-STI-2011-00110.

5. M.A. Baich, C.C. Herman, R.E. Eibling, M.F. Williams, and F.G. Smith, "Sludge Batch 4 Simulant Flowsheet Studies with ARP and MCU: Impat of MCU Organics," Savannah River National Laboratory, Aiken, SC, WSRC-TR-2005-00230.

6. C.C. Herman, M.F. Williams, S.L. Crump, T.L. White, D.R. Best, and E.K. Hansen, "DWPF Flowsheet Studies with Simulants to Determine Modular Caustic Side Solvent Extraction Unit Solvent Partitioning and Verify Actinide Removal Process Incorporation Strategy," Savannah River National Laboratory, Aiken, SC, WSRC-TR-2006-00063.

7. D.P. Lambert, M.F. Williams, S.L. Crump, R.E. Eibling, T.L. White, and D.R. Best, "DWPF Flowsheet Studies with Simulants to Determine MCU Solvent Build-up in Continuous Runs," Savannah River National Laboratory, Aiken, SC, WSRC-TR-200600154.

8. M.E. Stone, "Preliminary Evaluation of DWPF Impacts of Boric Acid Use in Cesium Strip for SWPF and MCU," Savannah River National Laboratory, Aiken, SC, SRNL-STI2010-00594.

9. D.C. Koopman, "Statistical Evaluation of Processing Data from the Rh-Ru-Hg Matrix Study," Savannah River National Laboratory, Aiken, SC, SRNL-STI-2009-00084.

10. D.C. Koopman, "Preparation, Characterization, and Preliminary Testing of a Simulant for the Hydrogen and Rheology Modifiers Program," Savannah River National Laboratory, Aiken, SC, SRNL-PSE-2007-00191.

11. M.E. Stone, "Lab-scale CPC Equipment Set-up," Savannah River National Laboratory, Aiken, SC, SRNL-L3100-2011-00127.

12. A. Erdemir, "Method to Improve Lubricity of Low Sulfur Diesel and Gasoline Fuels," United States of America 6,783,561, 2004. 


\section{Distribution:}

J.W. Amoroso, 999-W

A.B. Barnes, 999-W

D.R. Best, 999-W

A.L. Billings, 999-W

J.M. Bricker, 704-27S

H.H. Burns, 773-41A

D.A. Crowley, 773-43A

M.S. Deshpande, 241-121H

R.E. Edwards, 773-67A

T.B. Edwards, 999-W

T.L. Fellinger, 704-26S

S.D. Fink, 773-A

K.M. Fox, 999-W

M.W. Geeting, 241-152H

B.A. Gifford, 704-56H

J.M. Gillam, 766-H

M.S. Hay, 773-42A

C.C. Herman, 999-W

E.W. Holtzscheiter, 704-15S

R.N. Hinds, 704-S

J.F. Iaukea, 704-30S

P.R. Jackson, 703-46A

F.C. Johnson, 999-W
D.C. Koopman, 999-W

K.L. Lang, 704-27S

D.P. Lambert, 999-W

T.E. Laupa, 704-27S

P.L. Lee, 703-41A

D.H. McKenzie, 241-197H

S.L. Marra, 773-A

J.D. Newell, 999-W

B.A. Oard, 241-197H

J.E. Occhipinti, 704-S

D.K. Peeler, 999-W

F.M. Pennebaker, 773-42A

T.B. Peters, 773-42A

H.M. Pittman, 704-27S

J.W. Ray, 704-S

H.B. Shah, 766-H

D.C. Sherburne, 704-S

M.E. Smith, 704-30S

A.V. Staub, 704-27S

M.E. Stone, 999-W

J.P. Vaughan, 773-41A

K.H. Subramanian, 766-H

J.R. Zamecnik, 999-W 